\title{
Assessment of the Socio-Demographic Factors Associated with the Satisfaction Related to the Childbirth Experience
}

\author{
Elie Al Ahmar, Samir Tarraf \\ Faculty of Medicine and Medical Sciences, Holy Spirit University of Kaslik, Mount Lebanon, \\ Lebanon \\ Email: elieahmar@hotmail.com
}

Received 26 April 2014; revised 23 May 2014; accepted 18 June 2014

Copyright (C) 2014 by authors and Scientific Research Publishing Inc.

This work is licensed under the Creative Commons Attribution International License (CC BY). http://creativecommons.org/licenses/by/4.0/

(c) (i) Open Access

\begin{abstract}
Assessment of the socio-demographic factors associated with the satisfaction is related to the childbirth experience. Objective: A mother's satisfaction with the childbirth experience may have instant and lasting effects on her wellbeing, and on the bonding with her infant. The main aim of the study was to assess which socio-demographic factors are associated with this satisfaction. Most factors that authors agree on are: Pain intensity, personal control, self-efficacy, length of labor, method of delivery and numerous other demographic factors. Design: A cross-sectional study. Data was collected using a self-reported survey. Settings: The sample consisted of 100 women, selected from St Georges Hospital and CHU-NDS, who had to speak Arabic and had given birth in the past three days prior to interview. Methods: The multiple linear regressions and the mean test were used to assess which factors were associated with a positive childbirth experience. The Mackey childbirth satisfaction scale, three items from the Wijma delivery Expectancy/Experience questionnaire, a seven item mastery scale developed by Pearlin and Schooler and a background questionnaire were filled by women. Findings: Factors that were linked to a positive birth experience were: Higher age, multiparous women, higher education, high monthly income, unemployment, childbirth preparation, high personal control and self-efficacy, high childbirth and labor pain, fulfilled expectations, shorter period of labor and instrumented delivery. Conclusion: This study demonstrates that satisfaction with the childbirth experience is multi-dimensional with diverse factors foreseeing diverse dimensions of satisfaction.
\end{abstract}

\section{Keywords}

Childbirth Experience, Satisfaction, Personal Control, Self-Efficacy, Mother

How to cite this paper: Al Ahmar, E. and Tarraf, S. (2014) Assessment of the Socio-Demographic Factors Associated with the Satisfaction Related to the Childbirth Experience. Open Journal of Obstetrics and Gynecology, 4, 585-611. 


\section{Introduction}

For several years, the wellbeing of the mother and infant was the main center of attention that was emphasized on in the course of delivery. Nevertheless, throughout the previous twenty years, the mother's childbirth experience has procured mounting importance. A number of risk factors have been established to be noteworthy for a positive birth experience. Taking part in decision making, personal expectations, support from healthcare providers and health-care provider-patient relationship were also vigorous factors that influenced women's assessment of the birth experience, such as urgent cesarean-section, instrumental delivery, unpredicted complications, newborn transferred to neonatal intensive care unit, lack of support during and after delivery and socio-demographic factors.

Socio-demographic factors most researchers agree about—expectations about childbirth, labor pain, personal control and self-efficacy.

So the question arises to what extent the results of other studies concerning the relationship between the socio-psychological factors and childbirth experience can be generalized between countries and applied to our country Lebanon.

So my main objective is to study the impact of expectations about childbirth, the labor pain, personal control, self-efficacy and other numerous socio-demographic factors on the satisfaction related to the childbirth experience.

\section{Childbearing: Crucial Event in a Woman's Life}

Childbearing, a phase extending from conception until after giving birth, has been identified in literature as a major life event that can bring about many challenges for the woman and her family.

Its importance has been outlined by many; Rubin found that in order to acquire a mature female identity, there is a necessity of attainment of the motherhood role [1]. In addition, Brockington considered the process of childbearing as one of the most complex, and common, developmental events in the human experience [2].

Moreover, Childbirth represents a physical and psychological challenge, a course of action from which women can obtain profound feelings of empowerment and accomplishment [3] or on the contrary, feelings of rage, guilt, violation and melancholy [4].

\section{Importance of Assessing Psychological Status during Pregnancy, Childbirth and the Postnatal Period}

Due to its importance, pregnancy is recognized to be a shift in a woman's life associated with heightened levels of sentiments and psychological conditions [5].

Psychological status assessment must include a comprehensive assessment of all the dimensions that attribute to mood and emotional status for women during pregnancy, childbirth and the postnatal period.

\subsection{Anxiety and Depression in Pregnancy}

In the literature, postnatal depression (PND) is more valorized than depression during pregnancy. But psychological stress and anxiety during pregnancy have a key outcome on the fetus that lasts until at least middle childhood, and may persist into adulthood, being associated with emotional problems, late motor development, cognitive and behavioral disorders [6].

Furthermore, unfavorable clinical outcomes have been found linked to depression during pregnancy such as increased use of epidural anesthesia, cesarean section, instrumental deliveries and increased admission of neonates to intensive care units, spontaneous abortions, fetal structural abnormalities, greater risk of pre-eclampsia, preterm delivery and low birth weight infants [7].

In addition, antenatal depression has a deep and permanent impact on the long-term mental health of the mother. Associations have been established between prenatal depression and schizophrenia [8].

\subsection{Postnatal Depression}

Roughly $13 \%$ of all childbearing women will suffer from an episode of PND. The importance of PND lies in the possible negative outcomes on women and their families. Apart from imposing sorrow on the mother, PND 好 
weakens the marital relationship and damages the emotional and cognitive development of infant, particularly when coupled with other risk factors such as poverty. The confidential enquiry into maternal and child health 2000-2002 (Royal College of Obstetricians and Gynecologists, RGOG 2004) documented deaths from psychiatric causes as the principal cause of maternal mortality overall, referring the most to suicide [7].

Moreover in contrast with well mothers, mothers with PND state considerably higher rates of infant nourishing, crying and sleeping problems as well as relationship issues with their infant [9]. Influences of PND have been established in infants language skills, social and emotional development and intelligence quotients.

\subsection{Quality of Life}

Otchet et al. documented that physical functioning as measured by standard quality of life declines during normal pregnancy [10].

Nausea and vomiting in early pregnancy causes considerable lifestyle limitations on women, causing them to state alterations in family, social and occupational functioning as a result.

Evidence reveals a strong association between decrements in quality of life and depression.

In the post-natal period, we have elevated level of depressive symptoms due to the lowered health associated performance and perceived well-being in pregnant women [11]. For example, women with an episiotomy described disruption to daily life, insomnia, trouble bathing and carrying on usual daily activities. Consequently causing them anxiety and depression.

It seems apparent that quality of life may have a considerable role to play in the psychological well-being of pregnant woman and puerpera, with a potential proposal that detection and validation by care-givers of the need for pregnant women to create modifications in lifestyle will contribute to enhanced quality of life and reduced psychological sequelae [7].

\subsection{Sleep and Pregnancy}

Sleeping difficulties are regularly reported by pregnant women, and it has been recognized for some time that sleep can be troubled during pregnancy, especially during the period of 11 to 12 weeks of gestation.

Numerous evidences indicate that hormonal modifications in pregnancy and several physiological alterations that arise during pregnancy are also recognized to lead to disorders of normal sleep [7].

Associations connecting the sleep changes of pregnancy and postpartum depressed mood have also been assumed. Higher ratings of post-partum "blues" symptoms have been associated with greater sleep disturbances during pregnancy and labor [12], with postnatal blues mentioned as a risk factor for consequent PND.

So obviously, the harmful effects of reduced sleep quality consist of an impact on mood, cognitive functioning, and general psychological well-being.

\subsection{Self-Esteem}

Low self-esteem is a strong predictor factor for depressive symptoms.

Mounting evidence hint that self-esteem is a significant psychological entity that affect not only the experience of pregnancy, but as well maternal outcomes.

Mothers who have elevated self-esteem are capable of bearing up the stressors of early motherhood, which may impact on the sense of self-worth and contribute in lowering the incidence of PND [13].

Several studies have considered the association between fear of childbirth and self-esteem. Mothers with fear of childbirth will have a low self-esteem and are less likely to undergo a normal delivery often applying for a caesarean section [7]. This will lead eventually to deteriorated mood and diminished self-esteem. Furthermore low self-esteem has been coupled to symptoms of posttraumatic stress, preterm delivery and on the contrary high self esteem with higher birth weight neonates.

Another element that is related to self-esteem is body image satisfaction during pregnancy. Women who exercised more reacted positively to changes in their bodies, exhibiting higher self-esteem and lower physical discomfort.

In addition, Jenkin and Tiggemann found that women who maintained weight after delivery, and were less pleased with their post-natal silhouette, established a negative association with self esteem [14].

In conclusion, interventions that intend to grant emotional and psychological support to women within maternity care may require reflecting on self-esteem, as the significance of such interventions may be reliant on 
women’s personal self-esteem resource.

\section{Importance of Satisfaction with the Childbirth Experience}

\subsection{General Outline}

Patient satisfaction is a vital health product in today's cost conscious health field and is one of the most commonly reported outcome measures for quality of care and provision of health care services [15]. Health care providers, administrators and policymakers use patient satisfaction in order to evaluate the quality of care, craft decisions about the organization and provision of health care services, evade malpractice litigation and uphold a competitive spirit in the health care domain [16]. Consequently understanding women's satisfaction with their childbirth experience is pertinent to health care providers, administrators and policymakers as an indicator of quality of maternity care.

Additionally inferences were drawn indicating that the health and well-being of a woman and her new born is widely affected by patient's satisfaction with the childbirth experience. A woman's satisfaction with her childbirth experience might have abrupt and long-standing effects on her health and her relationship with her infant [16].

\subsection{Benefits of a Positive Childbirth Experience}

A pleasing childbirth experience adds to a woman's sense of achievement and self-esteem [17] and guides to expectations for future positive childbirth experiences [16].

The well being of the infant is tremendously affected by woman's own satisfaction with the childbirth experience. A mother's positive view regarding her birth experience has been associated to positive feelings toward her infant and adjustment to the maternal function [17].

In addition, it is believed that the configuration of a well-built link between a mother and her offspring can guide to a more affirmative parenting behavior and enhanced cognitive and neurobehavioral development of a child [18].

Also the consequences of a positive childbirth experience are improved self-confidence, attainment of skills and knowledge [17].

\subsection{Influences of a Negative Childbirth Experience}

In contrast, women who underwent disappointing births bear in mind the birth of their infant only with soreness, rage, fright, sorrow, or they recall nil which is indicative of traumatic amnesia [16].

A distressing and disappointing birth could direct to postpartum depression or post-traumatic stress disorder in which women experience again their labor in dreams and flashbacks that, in turn, set off tremendous misery. An inadequate childbirth experience may also lead to future abortions, a deficiency in the capacity of resuming sexual intercourse or inclination for a caesarean for following births [16].

Besides, women with a negative experience regarding their first delivery are also predisposed to longer periods in order to conceive their second baby and to desire fewer subsequent children [18].

These endpoints will have consequences on a woman's physical and emotional well-being, on her function as a mother and interpersonal parental relationships.

Additionally, harrowing births have influenced women's capability of breast-feeding and bonding with their offspring and have led to child neglect and abuse [16].On one hand, this collapse of bonding will have solemn long-term outcomes on the mother-child relationship, disturbing the infant's maturity and growth. And on the other hand, maternal consequences of poor bonding include lack of motherly feelings, tetchiness, resentment, and rejection of the newborn [18] [19].

\section{Socio-Psychological Factors Affecting Satisfaction with Childbirth Experience}

Most socio-psychological determinants affecting satisfaction with childbirth experience that researchers agree about are:

\subsection{Personal Control}

Personal control has been made known to be the most correlated with a positive childbirth experience. Numer- 
ous authors indicate that an insight of being in control during birth is fundamental to feeling content and empowered, still if expectations are disrespected. Even though pain control is the greatest short term answer for helping women to deal with childbirth, personal control grants a long term profit. If women partake actively and vigorously, they are empowered by the knowledge of being in control [20].

Women believed that if they obtained information throughout the course of labor, this facilitated them to be perceived as being in control: those who were left in the dark felt that information was being suspended from them for no obvious reason which caused a feeling of irritation by the circumstances and sensed that they should have obtained better information. Feeling in control was interrelated to women's interactions with professionals who could improve or detract from their experiences [21].

Moreover the concept of control differs from a woman to another: some women are worried about being in control over the course of labor like its duration however others their worries mainly involve the participation in decisions which are made about the organization of labor and birth. As a result, allowing women to craft informed choices and decisions are imperative factors which make women feel confident and satisfied with the childbirth experience [22].

Y. Hauck et al. specified that awareness of not being paid attention to or supported to be involved, produced feelings of being unsupported and isolated from birth experience [23].

Loss of control and disempowerment during labor and childbirth came through strongly as a fear for many of the women in the study of C. Fisher et al. [23] [24]. Women were terrified of being deprived of control over their bodies. Also loss of control broadened to feelings as being cruel to someone, demanding and racketing.

In addition, being in control was perceived as a positive component of labor, with the preponderance of women affirming that it was essential to maintain personal dignity during labor in order of achieving a positive childbirth experience. Also, Tina Lavender et al. outlined that participation in decision making in various aspects of care is vital to the personal control of women: major decisions women sought to make were choices concerning who should be in attendance at the delivery, which technique of pain relief they ought to receive and what position they should adopt at delivery [25].

As a result, personal control emerges dependent upon pregnant women on possessing options that allow choice, ample information and contribution in decision making. Loss of personal autonomy and control has been emphasized on as a key theme for women during labor and childbirth, advocating the advantage of care options that grant women greater levels of control [7].

\subsection{Self-Efficacy}

Self-efficacy is a person's belief of her own capability to carry out a certain behavior. In accordance with the exploitation of coping strategies to deal with pain, the greater a person's coping self-efficacy is; the greater is the probability of her executing that behavior in reality. Educating in cognitive coping strategies improved coping self-efficacy to bear up and decrease pain, which in turn was coupled with improved pain tolerance .From the childbirth literature, women with the utmost levels of self-efficacy for managing pain bared pain in labor the longest before applying for pain medication and consumed less pain medication throughout labor [26].

The question arises now on how self-efficacy is formed. It is created through a variety of routes including: past experience that is, how successful an individual considered the behavior has been in the past, vicarious experiences of coping behaviors, verbal coercion (such as prodding and strengthening) and the individual's level of emotional arousal. All of these can have a positive and negative impact on self-efficacy status. Referring this into coping with pain, persons require help in developing sentiments of confidence in their capacity of handling pain and anxiety in the course of a favored set of coping tactics, which they feel confident in attaining a profit. It is consequently imperative to recognize preceding efforts to manage pain and anxiety and how to promote employment of coping strategies[26].

Preceding conduct is an essential forecaster of successful coping strategy application as well as a significant supply of self efficacy facts, both of which have inferences for developing intentions to act.

Lowe's stated also that women who reported high intensity fear relied on others to make resolutions concerning their health and possessed drastically lower levels of self esteem and a reduced amount of satisfaction with the childbirth experience [24].

\subsection{Previous Expectations}

Expectations as an element of satisfaction is correlated to the requirement for the accustomed; which connotes 
that socially produced expectations impacts satisfaction. Expectations allude to a role system. The function of a laboring woman counts in a series of expectations regarding her own performance and people in other positions for example the midwife, the spouse, or the doctor. By requesting the expected of one's inner self and each individual in attendance, a feasible order is produced. Infringement of expectations troubles this order and jeopardizes both self-evaluations and bonds with others. That is to say, the divergence from what is standard or expected generates anguish. Satisfaction is a state of mind displaying the assessment of the birth experience as a whole weight against numerous antenatal principles and expectations. If expectations are fulfilled, the equivalent values and beliefs are guaranteed. If not, quarrels occur, which may generate agony. Still, intervening factors can play a cushioning role between the inconsistency and the response to it. Personal control is one of those mediators [20].

Many conceptions of satisfaction ascribe expectations to a major determining factor of satisfaction. Researchers have made known that women whose expectations for childbirth were fulfilled are more pleased than those whose expectations were not. Expectations linked to numerous facets of labor and delivery, like sentiments, the duration of labor, the must for interventions, the health state of the child at birth, and the encouragement of the spouse and the medical personnel, have been researched [20].

In addition, Y. Hauck et al. stated that expectations about labor pain had significant impact on satisfaction level, as a result potent antenatal preparation partakers allowed women to have reasonable expectations concerning pain levels, therefore guaranteeing that expectations were attainable. On the contrary, Kannan et al. showed that women who anticipated vaginal childbirth and consequently asked for epidural anesthesia were less contented with their experience, regardless of lower amount of pain [23].

\subsection{Pain Intensity}

C. Larsson et al. found that the recall of pain throughout delivery was exceedingly correlated to a negative birth experience. This was also true for women who were given painkillers 24 - $48 \mathrm{~h}$ after delivery, who displayed a threefold rise in the risk of experiencing a negative birth experience [18].

Therefore labor pain is one determinant linked to satisfaction with childbirth. Females who have undergone less labor pain have described higher levels of childbirth satisfaction weight against with women with more labor pain [16]. Mackey M.C. reported that $40 \%$ of women perceived pain as the nastiest part of the labor and delivery [27].

Interestingly, Wagner states that the heed a woman is given when she proceeds to a hospital to bring forth a child noticeably influences the pain she will supposedly encounter. Wagner documents that labor pain considerably amplifies when laboring in an unknown place, being encircled by strange individuals, undergoing unusual procedures, being left on your own during labor, being placed in a recumbency position, prohibited to move around freely, going through artificial rupture of membranes and by experiencing induction of labor or increase with medication [24].

Nonetheless elevated level of pain does not exclude a positive overall childbirth experience. Gaining control of pain may be perceived as a fundamental part of a self-actualizing experience. Some women expressed a feeling of accomplishment and gratification in their aptitude to deal with severe pain, which amplified their awareness of self-efficacy. Callister et al. noted that labor pain can be viewed as a chance for self-growth, spiritual development, as a coping process, control strategy or as power. Overcoming the pain of delivery promotes one's own build out as expressed by Grainger and McCool: "Birth is an important emotional and spiritual growth process, and enduring labor pain may be an integral part of that growth” [28].

\subsection{Childbirth Preparation}

Expert talks with the women can be a determining factor. They influence how women forge delivery and their level of confidence and personal control. Prenatal courses and prenatal consultations carried out by midwives and physicians took part in banishing and soothing fears, and boosting women's confidence and self-esteem. Accordingly, women's assumptions that they might flourishingly bear an infant, deliver and craft a conversion to motherliness, were armored or often altered to reveal this perspective [29].

Childbirth preparations for labor mostly consisted of parent craft sessions, exchange of views with acquaintances and relatives, delivery strategies, reading books and watching videos. These preparations helped out the women to deal with the real experience of labor. Initially, familiarity with pain assistance was established to be useful since it aided the women in making knowledgeable choices. Additionally, women believed that their 
planning helped them to cope psychologically with the labor, they believed to be in the know about labor, were capable of making decisions and were integrated in them and sensed to be in command during the labor [22].

But these classes provided support only if the group had connected before the babies were delivered, and if links were sustained for some significant amount of time afterwards [30].

\subsection{First-Time Mothers or Not}

Dread of the unfamiliar was a widespread subject matter running throughout first-time mothers. And it is not surprising at all as infant's delivery represent a key experience in the lives of females and their spouses, especially for primiparous women. They often stated that they did not know what to expect. While childbirth is becoming an imminent event, first-time mothers did not have the cultural and knowledge backgrounds that permit them to identify which questions they ought to be asking, frequently producing sense of uselessness and lack of skill [24].

Y. Hauck et al. found that the majority of women who evaluated their birth experience as positive and fulfilling were multiparae. In addition, these women discerned that their childbirth expectations were satisfied and attained. Moreover these women were unprejudiced and willing to compromise about their childbirth satisfaction. Additionally, multiparous women expatiated on the significance of being responsive and favorable to altering conditions that were outside the range of their control such as duration of labor and fetal discomfort. These women's expectations had a tendency to be emphasized on being taken into account and contribute in the course of delivery instead of precise concerns or requirements, for instance not undergoing an epidural, not undergoing an episiotomy, or reaching a precise form of birth [23].

\subsection{Instrumentation}

Women who underwent cesarean section were more displeased with reassurance and assistance from the midwife, the chance to contribute in decision making, the fact of being in control and the support perceived during lactation. A planned cesarean procedure was as well linked to a further negative birth experience. Women who undertook a cesarean intervention were less likely to consent with the declaration that the delivery was an exhilarating and joyful experience. They were, in contrast, more prone to think that the anesthetics during delivery were life-saving and that it was essential to stick with the staff's recommendations. Even though females in the cesarean set had their expectations satisfied, they stated that the most terrible thing was not being capable to make a decision on a type of childbirth. A high percentage of females who had intended to do a caesarean delivery felt that the baby's life is in jeopardy, and they reported that the birth experience let them think about not wanting further children [31].

Furthermore, mothers who favored and actually were delivered by caesarean sensed fright of childbirth on a higher level put side by side to women with a vaginal delivery. Also, the significance for women to play a part in the decision making as regards of mode of delivery was made clear. Still, regardless of a fulfilled request, mothers weren't contented with the course of decision making. Besides, these females had additional negative birth experiences that they ended up considering not conceiving new children and they were pleased to a lesser amount with prenatal and intrapartum care [31].

Despite an increase in medicalisation of childbirth, a large amount of females still look forward to be supported in the course of a natural vaginal delivery that is a positive, exhilarating experience. Conversely the truth about present-day maternity care, which is governed by increasing delivery intervention; above all caesarean section rates, use of forceps and vacuum; connotes that countless women are incapable to attain their expectations. Most of the time, this gives rise to feelings of disappointment, disillusion and disconnection amongst puerperants [23].

In addition, C. B. Kinsey et al. stated that a non-vaginal or traumatic childbirth can furthermore affect the bond connecting mother and child negatively, and this was associated to diminished maternal oxytocin levels during birth process [19].

But T. Lavender et al. found that women who saw themselves in a state of higher control were those whose delivery implicated the most interventions. Females participating in this study reported that interventions positively contributed to their childbirth experience when atypical labor pattern sets in [25].

\subsection{Epidural Effect}

According to L. C. Callister et al., some women wanted a natural pain killer-free delivery following an epidural 
with her preliminary one due to the deficiency of personal control that they sensed. They identified their prior delivery as a conventional one where the controlling role was played by the physician. They also stated that childbirth consisted more than just having a numb body. When they changed physicians and underwent a drug-free second birth, they announced that delivery was a bitter-sweet event with contradictory emotions of love and confrontation of pain climaxing in the delivery of the child [28].

\subsection{Prolonged Labor}

After extended labor, females portrayed and reported their emotions and experience as an experience of being held up in soreness and panic while being not in control and being reliant on others. Their state of being haunted by ache and fright, and of being worn out and helpless during labor, had had an enormous weight on the new mothers [32].

The soreness and terror lived by the mothers was viewed as a life-threatening event infused with profound feelings of dreadfulness and terror. Ryding et al. indicate that mothers panic for their own well-being and the well-being of their babies [32].

Additionally, as the long-drawn-out labor had appeared as a shocker, the risk for the self had been a risk for the physical integrity, because one's body had been viewed in good condition till the beginning of labor. The females had sensed that their sense of well-being and control was absent. They had lost their capacity to contribute in decisions regarding their care. The mothers had abruptly perceived themselves as mothers with difficult labor and had abandoned themselves to the physicians and midwives. It was like if they had unexpectedly become sick and had turned into victims of conditions that they had no control over, which required obstetric and medical care [32].

\section{Materials and Methods}

\subsection{Selection of Method}

This cross-sectional study molded the relationship between satisfaction with childbirth experience and labor/ childbirth pain, personal control, childbirth expectations, self efficacy, length of labor, mode of delivery and receiving epidural anesthesia or not collected from a self-reported survey. In order to contact as many women as possible in a short period of time, a translated questionnaire to the Arabic was given to women in a period of a three-day post-partum interval. The timing was selected to allow optimal time for recuperation from delivery, at the same time as still being on the verge of the experience, since we were concerned in the women's experience throughout her pregnancy, during her delivery and as well as in the post-partum.

\subsection{Settings}

Satisfaction with childbirth was studied in two different health care institutions:

"Centre Hospitalier Universitaire Notre-dame de Secours-Jbeil (CHUNDS)" which is considered as the leading healthcare institution in the Caza of Jbeil includes a Maternity Care Unit with a maximal capacity of 30 beds.

"St-Georges Hospital-Ajaltoun" which is considered as the leading healthcare institution in the Caza of Keserouwan includes a Maternity Care Unit with a maximal capacity of 26 beds.

\subsection{Sample Size}

The sample was recruited from the two Healthcare institutions mentioned above. The sample size consisted of 100 women that were interviewed with 50 women from each institution. The procurement of services such as epidural anesthesia, aptitude to execute caesarean section, easily contactable medical staff and instant accessibility to neonatal care was similar in the two units.

Inclusion criteria were wide:

Women had to speak and understand Arabic.

Women had given birth in the past three days before the interview.

The participation rate of the puerperants in filling the questionnaire was $100 \%$.

\subsection{Access and Ethical Considerations}

In order to gain access to the group to be studied, ethical approval was given from the chairman of the Depart- 
ment of Obstetrics \& Gynecology from each healthcare institution.

Women who matched with the inclusion criteria were recognized at the maternity ward. At first, the participants were approached by midwives who worked there. This was perceived to be crucial so that women wouldn't feel forced to join in this study. Each probable applicant received information orally, which consisted of explaining the objectives of the study, what their contribution would engage and asked them to participate by the midwife in charge of them. Women were knowledgeable about the right to turn down or pull out at any given time from the study upon their request.

Secrecy of the information collected was made certain and their privacy and anonymity were guaranteed. The data collected were managed solely by the researchers and exploited exclusively for the objectives of the study. A sketch of the information collected was provided to each participant for confirmation and to guarantee that the women interviewed didn’t sense that they were recognized.

\section{Measurement}

\subsection{Dependent Variables}

Satisfaction with the Childbirth experience is measured by the Mackey Childbirth Satisfaction Rating Scale. It is 34-item scale, which consists of six sub scales-partner (two items), self (nine items), midwife (nine items) and baby (three items) and physician (eight items) representing the behaviors of the major participants in the course of childbirth and one sub-dimension for global overall labor and delivery evaluation (three items). Respondents indicated their degree of satisfaction with each item on a 5-point likert scale. This scale was designed by Mackey and P. Goodman [16]. The scale was translated to the Arabic language. In the study of Goodman et al., the use of the scale was limited to low-risk post-partum women, with an age ranging between 18 - 46 years, with uncomplicated vaginal births of healthy full term newborns. But in our study, the use of the scale was extended to women of any age who delivers in any method possible. The possible score that women that use this scale can get ranges from a minimum of 34 to a maximum of 170 . The higher a woman scores the more satisfied she was during the childbirth experience. An acknowledgment must be given to Marlene C. Mackey who gave us her authorization to use the scale (Item-1).

\subsection{Independent Variables}

Two Visual analog scales (VAS)—one concerning labor and the other concerning delivery_-were used in order to measure the pain experienced ranging from No pain at all (0) to the worst unbearable pain (100). The measurement of labor and delivery pain by VAS was practiced frequently in the research on childbirth and has been trustworthy for quantifying the amount of pain. In contrast to other more compound measures, the visual analog scale is more desirable.

In order to measure personal control, the Wijma Delivery Expectancy/Experience Questionnaire (W-DEQ) was used. The W-DEQ was developed to measure a construct of fear related to childbirth during pregnancy and after delivery by asking the woman about her expectancies before and experiences after childbirth, respectively. Three items from the Wijma Delivery Expectancy/Experience Questionnaire (W-DEQ) were selected. The items are "I behaved extremely badly” to “ I didn’t behave badly at all”; “ I dared to totally surrender control to my body” to “ I did not dare surrender control to my body at all”; “ I lost total control of myself” to " I did not lose control of myself at all”, and they were scored from one to six. Because the entire scale is too broad in scope and shows overlap with the pain measure, only the control-related items were selected in order to assess the control experience during delivery. The score ranged from a minimum of three to maximum of eighteen. The higher the woman scored the less personal control she perceived.

In addition, we used the seven-item mastery scale developed by Pearlin and Schooler to measure self-efficacy. Mastery is the extent to which one's life-chances as being under one's own control in contrast to being fatalistically ruled. The seven items are as follows: "I often feel helpless in dealing with the problems of life", "I can do just about anything I really set my mind to do", “I have little control over the things that happen to me”, "Sometimes I feel that I'm being pushed around in life”, "There is really no way I can solve some of the problems I have”, "What happens tome in the future mostly depends on me”, "There is little I can do to change many of the important problems I have". Each item has five different answer options from "very much like me” to "Not at all like me". The score for the self-efficacy ranged from 7 to 30. The higher the mother scored, the higher was her self-efficacy. 
The question "To what degree was your experience of childbirth as expected?" was used to assess to which degree the mother's own expectations were fulfilled. The four answer options ranged from "completely in accordance with my expectations" to "not at all".

Childbirth characteristics such as length of labor, method of delivery and the use of epidural or not were controlled as well. The duration of labor was self-reported by participants in hours. How the infant was delivered was indicated by the method of delivery: spontaneous vaginal delivery, or instrumented vaginal delivery with the use of vacuum or forceps, or a Cesarean delivery.

In addition, socio-demographic factors were used as control variables: Level of education, age, income, parity, employment status and childbirth preparation.

A copy of the Arabic questionnaire can be found in the Annex (Item-2).

A copy of the English questionnaire can be found in the Annex (Item-3).

\section{Data Analysis}

Initial data analysis consisted of multiple linear regressions. This linear regression attempts to model the relationship between two or more explanatory variables and a response variable by fitting a linear equation to observed data. Every value of the independent variable $x$ is associated with a value of the dependent variable $y$.

The mean test was used in this study. In statistics, the mean test calculates subgroup means and related univariate statistics for dependent variables within categories of one or more independent variables.

Mean test is a technique used to compare means of two or more samples. This technique can be used only for numerical data.

In probability theory, the arithmetic mean of a sufficiently large number of iterates of independent random variables, each with a well-defined expected value and the well-defined variance, will be approximately normally distributed. That is, suppose that a sample is obtained containing a large number of observations, each observation being randomly generated in a way that does not depend on the values of the other observations, and that the arithmetic average of the observed values is computed. If this procedure is performed many times, the central limit theorem says that the computed values of the average will be distributed according to the normal distribution (commonly known as a "bell curve").

In probability and statistics, mean and expected values are used synonymously to refer to one measure of the central tendency either of a probability distribution or of the random variable characterized by that distribution. In the case of a discrete probability distribution of a random variable $X$, the mean is equal to the sum over every possible value weighted by the probability of that value; that is, it is computed by taking the product of each possible value $x$ of $X$ and its probability $P(x)$, and then adding all these products together, giving $\mu=\sum x P(x)$.

The standard deviation was calculated from the mean as follows:

$$
\begin{aligned}
\sigma & =\sqrt{E\left[(X-\mu)^{2}\right]}=\sqrt{E\left[X^{2}\right]+E[(-2 \mu X)]+E\left[\mu^{2}\right]} \\
& =\sqrt{E\left[X^{2}\right]-2 \mu E[X]+\mu^{2}}=\sqrt{E\left[X^{2}\right]-2 \mu^{2}+\mu^{2}} \\
& =\sqrt{E\left[X^{2}\right]-\mu^{2}}=\sqrt{E\left[X^{2}\right]-(E[X])^{2}}
\end{aligned}
$$

The Standard Deviation (SD) shows how much variation or dispersion from the average exists. A low standard deviation indicates that the data points tend to be very close to the mean (also called expected value); a high standard deviation indicates that the data points are spread out over a large range of values.

In this test, SD was used as a measure of certainty. The more the SD was low, the higher the association was between the independent variable and the satisfaction with the childbirth experience.

\section{Results}

First of all, the age of the participants ranged from less than 18 years old till more than 38 years old. For women aged $<18$ years of age the SD $=24.007$. Whereas for women aged $>38$ years of age the SD $=15.507$. So we deduce that patients who are older are more satisfied with the childbirth experience (see Table 1).

In addition, women who were primipare had an SD of 18.887 and females who were not first-time mothers had an SD of 18.122. We conclude that multiparous women were slightly more satisfied than primiparous 
women (see Table 2).

Table 1. Self partner baby nurse physician general overall * age.

\begin{tabular}{|c|c|c|c|c|c|c|c|c|}
\hline \multicolumn{2}{|c|}{ Age } & \multirow{2}{*}{$\begin{array}{c}\text { Self } \\
38.00\end{array}$} & \multirow{2}{*}{$\begin{array}{c}\text { Partner } \\
7.67\end{array}$} & \multirow{2}{*}{$\begin{array}{l}\text { Baby } \\
13.33\end{array}$} & \multirow{2}{*}{$\begin{array}{l}\text { Nurse } \\
41.00\end{array}$} & \multirow{2}{*}{$\begin{array}{c}\text { Physician } \\
34.00\end{array}$} & \multirow{2}{*}{$\begin{array}{c}\text { General } \\
12.33\end{array}$} & \multirow{2}{*}{$\begin{array}{r}\text { Overall } \\
146.33\end{array}$} \\
\hline & Mean & & & & & & & \\
\hline Less than 18 & Std. Deviation & 12.124 & 3.215 & 1.528 & 1.732 & 5.292 & 2.887 & 24.007 \\
\hline & Range & 21 & 6 & 3 & 3 & 10 & 5 & 45 \\
\hline & Mean & 33.89 & 8.06 & 13.28 & 37.83 & 33.22 & 12.00 & 138.28 \\
\hline \multirow[t]{3}{*}{$18-24$} & Std. Deviation & 7.836 & 2.437 & 2.081 & 8.611 & 7.826 & 1.715 & 22.096 \\
\hline & Range & 25 & 8 & 8 & 36 & 32 & 7 & 84 \\
\hline & Mean & 32.86 & 8.09 & 11.66 & 37.89 & 33.60 & 12.26 & 136.20 \\
\hline \multirow[t]{3}{*}{$25-31$} & Std. Deviation & 5.852 & 1.976 & 2.890 & 4.542 & 4.519 & 1.559 & 16.932 \\
\hline & Range & 26 & 7 & 12 & 20 & 18 & 6 & 63 \\
\hline & Mean & 36.05 & 7.92 & 12.38 & 39.46 & 34.78 & 12.62 & 143.22 \\
\hline \multirow[t]{3}{*}{$32-38$} & Std. Deviation & 5.405 & 1.949 & 2.314 & 4.438 & 4.510 & 1.934 & 17.568 \\
\hline & Range & 20 & 8 & 8 & 17 & 17 & 6 & 57 \\
\hline & Mean & 36.86 & 8.86 & 13.29 & 37.71 & 33.43 & 11.71 & 141.86 \\
\hline \multirow[t]{3}{*}{ Above 38} & Std. Deviation & 4.947 & 1.069 & 1.604 & 4.348 & 3.867 & 2.289 & 15.507 \\
\hline & Range & 14 & 2 & 3 & 13 & 11 & 6 & 45 \\
\hline & Mean & 34.66 & 8.06 & 12.38 & 38.54 & 33.97 & 12.31 & 139.87 \\
\hline \multirow[t]{2}{*}{ Total } & Std. Deviation & 6.328 & 2.019 & 2.485 & 5.383 & 5.179 & 1.807 & 18.212 \\
\hline & Range & 26 & 8 & 12 & 36 & 32 & 7 & 84 \\
\hline
\end{tabular}

Table 2. Self partner baby nurse physician general overall * number of kids.

\begin{tabular}{|c|c|c|c|c|c|c|c|c|}
\hline \multicolumn{2}{|c|}{ Number of Kids } & \multirow{2}{*}{$\begin{array}{c}\text { Self } \\
33.26\end{array}$} & \multirow{2}{*}{$\begin{array}{c}\text { Partner } \\
8.16\end{array}$} & \multirow{2}{*}{$\begin{array}{l}\text { Baby } \\
12.29\end{array}$} & \multirow{2}{*}{$\begin{array}{l}\text { Nurse } \\
39.23\end{array}$} & \multirow{2}{*}{$\begin{array}{c}\text { Physician } \\
34.26\end{array}$} & \multirow{2}{*}{$\begin{array}{c}\text { General } \\
12.26\end{array}$} & \multirow{2}{*}{$\begin{array}{l}\text { Overall } \\
139.45\end{array}$} \\
\hline & Mean & & & & & & & \\
\hline First Baby & Std. Deviation & 6.653 & 2.131 & 2.545 & 4.492 & 4.502 & 1.712 & 18.887 \\
\hline & Range & 26 & 7 & 9 & 18 & 17 & 6 & 73 \\
\hline & Mean & 35.34 & 8.01 & 12.47 & 38.26 & 33.87 & 12.34 & 140.22 \\
\hline \multirow[t]{3}{*}{ Not the First Baby } & Std. Deviation & 6.154 & 1.996 & 2.458 & 5.779 & 5.518 & 1.874 & 18.122 \\
\hline & Range & 25 & 8 & 12 & 36 & 32 & 7 & 84 \\
\hline & Mean & 34.69 & 8.06 & 12.41 & 38.57 & 33.99 & 12.31 & 139.98 \\
\hline \multirow[t]{2}{*}{ Total } & Std. Deviation & 6.355 & 2.029 & 2.474 & 5.404 & 5.201 & 1.816 & 18.272 \\
\hline & Range & 26 & 8 & 12 & 36 & 32 & 7 & 84 \\
\hline
\end{tabular}


Moreover, the education of women ranged from high school or less until college or more. Data analysis showed that women who reached college or more (SD = 16.984) were more satisfied with the childbirth experience then women with an education of high school or less $(\mathrm{SD}=20.660)$ (see Table 3$)$.

Also, women who were unemployed $(\mathrm{SD}=16.954)$ were more satisfied with the childbirth experience than employed mothers (SD = 19.252) (see Table 4).

Furthermore, the participants' salary ranged from less than 750,000 L.L. to more than 10,000,000 L.L. The higher the salary was, the more satisfied was the mother (SD Salary < 750,000 L.L. $=24.390$; $S D$ Salary > 10,000,000 L.L. $=$ 14.142) (see Table 5).

Additionally, the option of childbirth preparations were: Made a plan, read books and watched videos, took lessons and nothing. The most satisfied women were the ones who read books and watched videos with an SD of 14.085 (see Table 6).

The women participating in this study scored on the personal control scale from 4 to 13 . The higher the score was; the less personal control was perceived. So women who sensed more personal control, were more satisfied with the childbirth experience ( $S D_{\text {Personal Control score of } 4}=5.164$; $S_{\text {Personal Control score of } 13}=11.618$ ) (see Table 7).

The range of the Self-efficacy score was from 18 to 35. The higher the score was, the more self-efficacy was

Table 3. Self partner baby nurse physician general overall ${ }^{*}$ education.

\begin{tabular}{|c|c|c|c|c|c|c|c|c|}
\hline \multicolumn{2}{|c|}{ Education } & \multirow{2}{*}{$\begin{array}{c}\text { Self } \\
35.97\end{array}$} & \multirow{2}{*}{$\begin{array}{c}\text { Partner } \\
8.34\end{array}$} & \multirow{2}{*}{$\begin{array}{l}\text { Baby } \\
12.23\end{array}$} & \multirow{2}{*}{\begin{tabular}{|l} 
Nurse \\
38.26
\end{tabular}} & \multirow{2}{*}{$\begin{array}{c}\text { Physician } \\
33.77\end{array}$} & \multirow{2}{*}{$\begin{array}{c}\text { General } \\
12.34\end{array}$} & \multirow{2}{*}{$\begin{array}{r}\text { Overal } \\
140.91\end{array}$} \\
\hline & Mean & & & & & & & \\
\hline \multirow[t]{3}{*}{ High School or Less } & Std. Deviation & 6.294 & 2.209 & 2.921 & 6.563 & 6.445 & 2.043 & 20.660 \\
\hline & Range & 25 & 8 & 12 & 36 & 32 & 7 & 84 \\
\hline & Mean & 33.95 & 7.91 & 12.46 & 38.69 & 34.08 & 12.29 & 139.31 \\
\hline \multirow[t]{3}{*}{ College or More } & Std. Deviation & 6.281 & 1.910 & 2.237 & 4.677 & 4.403 & 1.684 & 16.894 \\
\hline & Range & 26 & 8 & 9 & 20 & 17 & 6 & 68 \\
\hline & Mean & 34.66 & 8.06 & 12.38 & 38.54 & 33.97 & 12.31 & 139.87 \\
\hline \multirow[t]{2}{*}{ Total } & Std. Deviation & 6.328 & 2.019 & 2.485 & 5.383 & 5.179 & 1.807 & 18.212 \\
\hline & Range & 26 & 8 & 12 & 36 & 32 & 7 & 84 \\
\hline
\end{tabular}

Table 4. Self partner baby nurse physician general overall ${ }^{*}$ employment status.

\begin{tabular}{|c|c|c|c|c|c|c|c|c|}
\hline \multicolumn{2}{|c|}{ Employment Status } & \multirow{2}{*}{$\begin{array}{c}\text { Self } \\
34.80\end{array}$} & \multirow{2}{*}{$\begin{array}{c}\text { Partner } \\
8.24\end{array}$} & \multirow{2}{*}{$\begin{array}{l}\text { Baby } \\
12.63\end{array}$} & \multirow{2}{*}{$\begin{array}{l}\text { Nurse } \\
38.95\end{array}$} & \multirow{2}{*}{$\begin{array}{c}\text { Physician } \\
34.20\end{array}$} & \multirow{2}{*}{$\begin{array}{c}\text { General } \\
12.41\end{array}$} & \multirow{2}{*}{$\begin{array}{l}\text { Overall } \\
141.24\end{array}$} \\
\hline & Mean & & & & & & & \\
\hline \multirow[t]{3}{*}{ Employed } & Std. Deviation & 7.121 & 1.997 & 2.046 & 5.069 & 4.966 & 1.774 & 19.252 \\
\hline & Range & 26 & 8 & 9 & 18 & 17 & 6 & 78 \\
\hline & Mean & 34.94 & 8.02 & 12.24 & 38.11 & 33.74 & 12.28 & 139.24 \\
\hline \multirow[t]{3}{*}{ Unemployed } & Std. Deviation & 4.977 & 2.005 & 2.691 & 5.689 & 5.402 & 1.785 & 16.954 \\
\hline & Range & 21 & 8 & 12 & 36 & 32 & 7 & 84 \\
\hline & Mean & 34.88 & 8.12 & 12.41 & 38.47 & 33.94 & 12.34 & 140.11 \\
\hline \multirow[t]{2}{*}{ Total } & Std. Deviation & 5.962 & 1.994 & 2.430 & 5.418 & 5.196 & 1.772 & 17.910 \\
\hline & Range & 26 & 8 & 12 & 36 & 32 & 7 & 84 \\
\hline
\end{tabular}


Table 5. Self partner baby nurse physician general overall * salary.

\begin{tabular}{|c|c|c|c|c|c|c|c|c|}
\hline \multicolumn{2}{|l|}{ Salary } & \multirow{2}{*}{$\begin{array}{c}\text { Self } \\
36.12\end{array}$} & \multirow{2}{*}{$\begin{array}{c}\text { Partner } \\
9.25\end{array}$} & \multirow{2}{*}{$\begin{array}{l}\text { Baby } \\
12.38\end{array}$} & \multirow{2}{*}{$\begin{array}{l}\text { Nurse } \\
37.25\end{array}$} & \multirow{2}{*}{$\begin{array}{c}\text { Physician } \\
33.50\end{array}$} & \multirow{2}{*}{$\begin{array}{c}\text { General } \\
12.00\end{array}$} & \multirow{2}{*}{$\begin{array}{l}\text { Overal } \\
140.50\end{array}$} \\
\hline & Mean & & & & & & & \\
\hline \multirow[t]{3}{*}{ Less than 750,000 L.L } & Std. Deviation & 3.907 & 1.488 & 2.134 & 11.793 & 10.664 & 2.138 & 24.390 \\
\hline & Range & 10 & 4 & 6 & 36 & 32 & 7 & 79 \\
\hline & Mean & 35.19 & 8.58 & 13.19 & 39.96 & 35.08 & 12.54 & 144.54 \\
\hline \multirow[t]{3}{*}{ 750,000 - 1,500,000 L.L } & Std. Deviation & 8.414 & 1.901 & 1.812 & 4.054 & 5.011 & 1.772 & 18.730 \\
\hline & Range & 25 & 7 & 6 & 18 & 18 & 6 & 78 \\
\hline & Mean & 34.22 & 7.61 & 11.90 & 38.29 & 33.75 & 12.12 & 137.88 \\
\hline \multirow[t]{3}{*}{ 1,500,000 - 5,000,000 L.L } & Std. Deviation & 5.756 & 2.040 & 2.872 & 4.211 & 3.882 & 1.705 & 16.562 \\
\hline & Range & 26 & 8 & 12 & 15 & 13 & 6 & 68 \\
\hline & Mean & 34.31 & 7.77 & 12.31 & 37.08 & 32.46 & 12.46 & 136.38 \\
\hline \multirow[t]{3}{*}{$5,000,000$ - 10,000,000 L.L } & Std. Deviation & 5.692 & 2.088 & 1.974 & 6.264 & 5.592 & 2.106 & 20.110 \\
\hline & Range & 17 & 7 & 6 & 20 & 17 & 6 & 63 \\
\hline & Mean & 35.50 & 10.00 & 14.50 & 41.00 & 37.00 & 14.50 & 150.00 \\
\hline \multirow[t]{3}{*}{ More than 10,000,000 L.L } & Std. Deviation & 2.121 & 0.000 & 0.707 & 4.243 & 4.243 & 0.707 & 14.142 \\
\hline & Range & 3 & 0 & 1 & 6 & 6 & 1 & 20 \\
\hline & Mean & 34.66 & 8.06 & 12.38 & 38.54 & 33.97 & 12.31 & 139.87 \\
\hline \multirow[t]{2}{*}{ Total } & Std. Deviation & 6.328 & 2.019 & 2.485 & 5.383 & 5.179 & 1.807 & 18.212 \\
\hline & Range & 26 & 8 & 12 & 36 & 32 & 7 & 84 \\
\hline
\end{tabular}

perceived. It was concluded that women who sensed more the self-efficacy, were more satisfied with the childbirth experience $\left(\mathrm{SD}_{\text {self-efficacy score of } 18}=36.770\right.$; $\left.\mathrm{SD}_{\text {self-efficacy score of } 35}=9.192\right)$ (see Table 8 ).

The amount of labor pain experienced indicated by the VAS ranged from 0 (no pain at all) to 100 (worst pain imaginable). After data analysis was done, women who experienced a higher amount of pain were more satisfied with the childbirth experience (SD VAS of $0=21.92$; SD $_{\text {VAS of } 100}=7.481$ ) (see Table 9 ).

The amount of childbirth pain experienced indicated by the VAS ranged from 0 (No pain at all) to 100 (Worst pain imaginable). After data analysis was done, women who experienced a higher amount of pain were slightly more satisfied with the childbirth experience $\left(\mathrm{SD}_{\mathrm{VAS} \text { of } 0}=15.405\right.$; $\mathrm{SD}_{\mathrm{VAS}}$ of $\left.100=12.119\right)$ (see Table 10 ).

Also it was noted that more a woman's expectations were fulfilled, their satisfaction with the childbirth experience was higher $\left(\mathrm{SD}_{\text {Childbirth expectations not met at all }}=27.977\right.$; $\mathrm{SD}_{\text {Childbirth expectations totally met }}=21.333$ ) (see Table 11).

Plus, total length of labor reported was from 0.16 hours to 17 hours. It was deduced that the less time the female spent in labor, the more she was satisfied with the childbirth experience ( $S D$ length of labor 0.16 hrs $=12.702$; $\mathrm{SD}_{\text {length of labor } 17 \text { hrs }}=16.971$ ) (see Table 12).

Furthermore, the method of delivery that the women underwent included: normal vaginal delivery, use of forceps or vacuum extraction and cesarean. It was concluded that women who faced the use of the forceps or a vacuum extraction during the delivery had the highest satisfaction rate with a slight advantage to the cesarean group $\left(\mathrm{SD}_{\text {use of forceps or vacuum extractor }}=16.607 ; \mathrm{SD}_{\text {vaginal birth }}=21.313 ; \mathrm{SD}_{\text {cesarean }}=16.752\right)$ (see Table 13).

Finally, the women who had received epidural anesthesia were found to be more satisfied with the childbirth experience than the women who had not $\left(\mathrm{SD}_{\text {received epidural anesthesia }}=16.894 ; \mathrm{SD}_{\text {did not receive epidural anesthesia }}=27.880\right.$ ) (see Table 14). 
Table 6. Self partner baby nurse physician general overall * labor preparation.

\begin{tabular}{|c|c|c|c|c|c|c|c|c|}
\hline \multicolumn{2}{|c|}{ Labor Preparation } & \multirow{2}{*}{$\begin{array}{c}\text { Self } \\
37.00\end{array}$} & \multirow{2}{*}{$\begin{array}{c}\text { Partner } \\
7.33\end{array}$} & \multirow{2}{*}{$\begin{array}{l}\text { Baby } \\
11.33\end{array}$} & \multirow{2}{*}{$\begin{array}{l}\text { Nurse } \\
40.00\end{array}$} & \multirow{2}{*}{$\begin{array}{c}\text { Physician } \\
35.67\end{array}$} & \multirow{2}{*}{$\begin{array}{c}\text { General } \\
13.00\end{array}$} & \multirow{2}{*}{$\begin{array}{l}\text { Overall } \\
144.33\end{array}$} \\
\hline & Mean & & & & & & & \\
\hline \multirow[t]{3}{*}{ Took Lessons } & Std. Deviation & 5.568 & 4.619 & 3.786 & 4.359 & 3.786 & 1.000 & 18.877 \\
\hline & Range & 11 & 8 & 7 & 8 & 7 & 2 & 37 \\
\hline & Mean & 29.17 & 6.50 & 10.33 & 38.50 & 31.50 & 10.83 & 126.83 \\
\hline \multirow[t]{3}{*}{ Made a Plan } & Std. Deviation & 9.411 & 2.345 & 3.830 & 4.637 & 6.979 & 1.472 & 25.733 \\
\hline & Range & 25 & 6 & 8 & 11 & 17 & 4 & 61 \\
\hline & Mean & 33.00 & 7.61 & 12.26 & 37.74 & 33.32 & 12.21 & 136.13 \\
\hline \multirow{3}{*}{$\begin{array}{l}\text { Red Books and Watched } \\
\text { Movies }\end{array}$} & Std. Deviation & 5.261 & 1.980 & 2.036 & 4.892 & 4.173 & 1.436 & 14.085 \\
\hline & Range & 23 & 8 & 7 & 20 & 13 & 6 & 60 \\
\hline & Mean & 36.29 & 8.60 & 12.71 & 39.00 & 34.58 & 12.50 & 143.58 \\
\hline \multirow[t]{3}{*}{ None } & Std. Deviation & 6.226 & 1.706 & 2.484 & 5.924 & 5.686 & 2.063 & 19.275 \\
\hline & Range & 25 & 7 & 12 & 36 & 32 & 7 & 84 \\
\hline & Mean & 34.62 & 8.05 & 12.35 & 38.52 & 33.94 & 12.30 & 139.73 \\
\hline \multirow[t]{2}{*}{ Total } & Std. Deviation & 6.345 & 2.027 & 2.484 & 5.405 & 5.196 & 1.815 & 18.249 \\
\hline & Range & 26 & 8 & 12 & 36 & 32 & 7 & 84 \\
\hline
\end{tabular}

Table 7. Self partner baby nurse physician general overall * personal control.

\begin{tabular}{|c|c|c|c|c|c|c|c|c|}
\hline & nal Control & Self & Partner & Baby & Nurse & Physician & General & Overall \\
\hline \multirow{3}{*}{4} & Mean & 42.67 & 10.00 & 14.67 & 44.33 & 39.67 & 14.33 & 165.67 \\
\hline & Std. Deviation & 2.944 & 0.000 & 0.816 & 1.033 & 0.516 & 0.816 & 5.164 \\
\hline & Range & 6 & 0 & 2 & 2 & 1 & 2 & 11 \\
\hline \multirow{3}{*}{5} & Mean & 34.00 & 8.67 & 14.00 & 40.33 & 31.33 & 12.33 & 140.67 \\
\hline & Std. Deviation & 5.292 & 2.309 & 1.000 & 3.215 & 7.638 & 1.155 & 19.009 \\
\hline & Range & 10 & 4 & 2 & 6 & 15 & 2 & 38 \\
\hline \multirow{3}{*}{6} & Mean & 35.67 & 9.33 & 13.67 & 39.00 & 33.33 & 14.00 & 145.00 \\
\hline & Std. Deviation & 0.577 & 1.155 & 1.528 & 5.000 & 4.163 & 1.000 & 10.440 \\
\hline & Range & 1 & 2 & 3 & 10 & 8 & 2 & 19 \\
\hline \multirow{3}{*}{7} & Mean & 35.00 & 8.67 & 12.17 & 40.33 & 36.67 & 11.33 & 144.17 \\
\hline & Std. Deviation & 6.387 & 1.633 & 1.472 & 5.046 & 4.457 & 1.366 & 18.071 \\
\hline & Range & 17 & 4 & 4 & 12 & 9 & 4 & 44 \\
\hline
\end{tabular}




\section{Continued}

\begin{tabular}{|c|c|c|c|c|c|c|c|c|}
\hline & Mean & 35.52 & 8.05 & 11.81 & 39.81 & 35.86 & 13.33 & 144.14 \\
\hline \multirow[t]{3}{*}{8} & Std. Deviation & 3.803 & 2.202 & 3.281 & 4.729 & 3.497 & .913 & 13.496 \\
\hline & Range & 17 & 7 & 12 & 20 & 12 & 3 & 60 \\
\hline & Mean & 33.88 & 8.13 & 12.31 & 35.69 & 31.56 & 11.56 & 133.13 \\
\hline \multirow[t]{3}{*}{9} & Std. Deviation & 6.292 & 1.586 & 1.957 & 8.300 & 7.420 & 1.999 & 20.858 \\
\hline & Range & 25 & 7 & 7 & 36 & 32 & 7 & 84 \\
\hline & Mean & 33.81 & 7.33 & 12.05 & 37.19 & 32.33 & 11.90 & 134.62 \\
\hline \multirow[t]{3}{*}{10} & Std. Deviation & 6.088 & 2.415 & 2.376 & 4.512 & 4.029 & 2.119 & 17.255 \\
\hline & Range & 21 & 8 & 8 & 17 & 13 & 6 & 51 \\
\hline & Mean & 33.42 & 7.75 & 11.83 & 38.00 & 33.67 & 12.08 & 136.75 \\
\hline \multirow[t]{3}{*}{11} & Std. Deviation & 8.754 & 2.261 & 3.215 & 3.490 & 4.334 & 1.621 & 21.592 \\
\hline & Range & 26 & 6 & 9 & 13 & 13 & 5 & 66 \\
\hline & Mean & 35.75 & 8.50 & 12.75 & 39.00 & 32.50 & 11.25 & 139.75 \\
\hline \multirow[t]{3}{*}{12} & Std. Deviation & 7.500 & 1.915 & 2.872 & 4.967 & 7.937 & 2.630 & 26.107 \\
\hline & Range & 16 & 4 & 6 & 11 & 18 & 6 & 55 \\
\hline & Mean & 30.50 & 7.67 & 12.83 & 39.00 & 35.33 & 11.83 & 137.17 \\
\hline \multirow[t]{3}{*}{13} & Std. Deviation & 9.607 & 1.506 & 1.169 & 5.020 & 4.227 & 1.169 & 11.618 \\
\hline & Range & 25 & 4 & 3 & 12 & 9 & 3 & 31 \\
\hline & Mean & 33.00 & 7.00 & 13.00 & 37.00 & 31.00 & 11.00 & 132.00 \\
\hline \multirow[t]{3}{*}{14} & Std. Deviation & 0.000 & 0.000 & 0.000 & 0.000 & 0.000 & 0.000 & 0.000 \\
\hline & Range & 0 & 0 & 0 & 0 & 0 & 0 & 0 \\
\hline & Mean & 34.66 & 8.06 & 12.38 & 38.54 & 33.97 & 12.31 & 139.87 \\
\hline \multirow[t]{2}{*}{ Total } & Std. Deviation & 6.328 & 2.019 & 2.485 & 5.383 & 5.179 & 1.807 & 18.212 \\
\hline & Range & 26 & 8 & 12 & 36 & 32 & 7 & 84 \\
\hline
\end{tabular}

\section{Discussion}

Age in this study has been identified as a variable influencing childbirth satisfaction. By that, women with an older age were more satisfied with the childbirth experience than the younger ones. This finding suggests that older females have lower childbirth expectations, more realistic ones which will be easily met in comparison to the younger mothers. In addition, the previous women due to their young age may have a short experience in life which will reflect tremendously on their personal control and self-efficacy. In consequence, this will lower their overall childbirth satisfaction.

Moreover, multiparous women were found to be more satisfied with the childbirth experience than primiparous women. My results confirm with the findings according to C. Fisher et al. [24] and Y. Hauck et al. [23]. It is 
Table 8. Self partner baby nurse physician general overall * self-efficacy.

\begin{tabular}{|c|c|c|c|c|c|c|c|c|}
\hline & Self-Efficacy & Self & Partner & Baby & Nurse & Physician & General & Overal \\
\hline \multirow{3}{*}{15} & Mean & 31.00 & 8.00 & 12.00 & 34.00 & 31.00 & 10.00 & 126.00 \\
\hline & Std. Deviation & . & . & . & . & . & . & . \\
\hline & Range & 0 & 0 & 0 & 0 & 0 & 0 & 0 \\
\hline \multirow{3}{*}{18} & Mean & 35.00 & 9.00 & 13.00 & 36.50 & 33.50 & 12.00 & 139.00 \\
\hline & Std. Deviation & 7.071 & 1.414 & 2.828 & 12.021 & 9.192 & 4.243 & 36.770 \\
\hline & Range & 10 & 2 & 4 & 17 & 13 & 6 & 52 \\
\hline \multirow{3}{*}{19} & Mean & 19.00 & 4.00 & 6.00 & 35.00 & 28.00 & 10.00 & 102.00 \\
\hline & Std. Deviation & 0.000 & 0.000 & 0.000 & 0.000 & 0.000 & 0.000 & 0.000 \\
\hline & Range & 0 & 0 & 0 & 0 & 0 & 0 & 0 \\
\hline \multirow{3}{*}{20} & Mean & 31.17 & 7.17 & 12.17 & 36.00 & 30.67 & 11.67 & 128.83 \\
\hline & Std. Deviation & 9.453 & 2.994 & 2.483 & 6.419 & 5.820 & 2.251 & 26.011 \\
\hline & Range & 25 & 7 & 6 & 16 & 16 & 5 & 68 \\
\hline \multirow{3}{*}{21} & Mean & 34.81 & 8.19 & 11.44 & 38.94 & 33.81 & 12.50 & 139.69 \\
\hline & Std. Deviation & 5.776 & 1.721 & 3.444 & 3.924 & 4.792 & 2.191 & 18.406 \\
\hline & Range & 17 & 4 & 12 & 10 & 18 & 6 & 58 \\
\hline \multirow{3}{*}{22} & Mean & 32.14 & 9.00 & 12.29 & 38.43 & 34.57 & 12.14 & 138.57 \\
\hline & Std. Deviation & 5.146 & 1.732 & 2.215 & 4.117 & 5.028 & 1.574 & 16.762 \\
\hline & Range & 16 & 4 & 6 & 11 & 13 & 4 & 45 \\
\hline \multirow{3}{*}{23} & Mean & 29.83 & 8.33 & 12.33 & 38.50 & 34.83 & 11.83 & 135.67 \\
\hline & Std. Deviation & 7.757 & .816 & 1.366 & 5.320 & 4.215 & 1.169 & 1.633 \\
\hline & Range & 16 & 2 & 4 & 12 & 10 & 3 & 5 \\
\hline \multirow{3}{*}{24} & Mean & 35.57 & 7.00 & 11.29 & 38.29 & 34.86 & 11.57 & 138.57 \\
\hline & Std. Deviation & 4.962 & 3.109 & 3.200 & 3.546 & 3.485 & 1.272 & 13.240 \\
\hline & Range & 17 & 8 & 8 & 10 & 9 & 4 & 39 \\
\hline \multirow{3}{*}{25} & Mean & 35.13 & 7.75 & 13.88 & 40.38 & 33.75 & 12.50 & 143.37 \\
\hline & Std. Deviation & 6.875 & 2.866 & 1.356 & 3.378 & 5.800 & 1.773 & 19.683 \\
\hline & Range & 20 & 8 & 3 & 10 & 17 & 5 & 52 \\
\hline \multirow{3}{*}{26} & Mean & 33.54 & 7.85 & 12.23 & 39.08 & 33.85 & 11.85 & 138.38 \\
\hline & Std. Deviation & 4.390 & 1.214 & 1.878 & 2.929 & 3.262 & 1.725 & 9.215 \\
\hline & Range & 18 & 4 & 7 & 10 & 11 & 6 & 30 \\
\hline
\end{tabular}




\section{Continued}

\begin{tabular}{|c|c|c|c|c|c|c|c|c|}
\hline & Mean & 38.00 & 9.50 & 14.00 & 41.25 & 36.75 & 13.75 & 153.25 \\
\hline \multirow[t]{3}{*}{27} & Std. Deviation & 6.272 & 1.000 & 1.414 & 6.185 & 5.252 & 1.500 & 20.710 \\
\hline & Range & 15 & 2 & 3 & 13 & 11 & 3 & 47 \\
\hline & Mean & 37.67 & 8.00 & 13.33 & 40.00 & 35.00 & 13.00 & 147.00 \\
\hline \multirow[t]{3}{*}{28} & Std. Deviation & 7.506 & 2.000 & 1.528 & 5.000 & 5.000 & 2.646 & 19.925 \\
\hline & Range & 15 & 4 & 3 & 10 & 10 & 5 & 35 \\
\hline & Mean & 38.25 & 6.50 & 13.00 & 37.75 & 33.00 & 13.00 & 141.50 \\
\hline \multirow[t]{3}{*}{29} & Std. Deviation & 1.500 & 1.732 & 2.449 & 1.500 & 1.155 & 1.155 & 5.260 \\
\hline & Range & 3 & 3 & 5 & 3 & 2 & 2 & 10 \\
\hline & Mean & 33.80 & 7.80 & 12.60 & 35.60 & 33.40 & 13.00 & 135.20 \\
\hline \multirow[t]{3}{*}{30} & Std. Deviation & 4.494 & 2.864 & 2.881 & 6.877 & 3.975 & .707 & 19.123 \\
\hline & Range & 11 & 7 & 6 & 19 & 11 & 2 & 53 \\
\hline & Mean & 39.00 & 9.33 & 13.33 & 29.67 & 26.33 & 10.67 & 128.33 \\
\hline \multirow[t]{3}{*}{31} & Std. Deviation & 4.583 & 1.155 & .577 & 18.583 & 16.503 & 2.309 & 39.068 \\
\hline & Range & 9 & 2 & 1 & 36 & 32 & 4 & 77 \\
\hline & Mean & 44.33 & 10.00 & 14.33 & 45.00 & 40.00 & 14.67 & 168.33 \\
\hline \multirow[t]{3}{*}{32} & Std. Deviation & 1.155 & .000 & 1.155 & .000 & .000 & .577 & 2.887 \\
\hline & Range & 2 & 0 & 2 & 0 & 0 & 1 & 5 \\
\hline & Mean & 38.00 & 8.75 & 12.00 & 38.00 & 35.00 & 12.25 & 144.00 \\
\hline \multirow[t]{3}{*}{33} & Std. Deviation & 5.477 & .957 & 1.414 & 4.690 & 3.916 & 1.258 & 15.811 \\
\hline & Range & 13 & 2 & 3 & 11 & 9 & 3 & 33 \\
\hline & Mean & 36.00 & 10.00 & 12.00 & 41.00 & 36.00 & 14.00 & 149.00 \\
\hline \multirow[t]{3}{*}{34} & Std. Deviation & . & . & . & . & . & . & . \\
\hline & Range & 0 & 0 & 0 & 0 & 0 & 0 & 0 \\
\hline & Mean & 37.60 & 8.40 & 13.80 & 41.60 & 37.40 & 13.20 & 152.00 \\
\hline \multirow[t]{3}{*}{35} & Std. Deviation & 1.140 & .894 & 1.095 & 3.362 & 3.130 & .837 & 9.192 \\
\hline & Range & 3 & 2 & 3 & 9 & 8 & 2 & 23 \\
\hline & Mean & 34.66 & 8.06 & 12.38 & 38.54 & 33.97 & 12.31 & 139.87 \\
\hline \multirow[t]{2}{*}{ Total } & Std. Deviation & 6.328 & 2.019 & 2.485 & 5.383 & 5.179 & 1.807 & 18.212 \\
\hline & Range & 26 & 8 & 12 & 36 & 32 & 7 & 84 \\
\hline
\end{tabular}


Table 9. Self partner baby nurse physician general overall * labor pain.

\begin{tabular}{|c|c|c|c|c|c|c|c|c|}
\hline & Labor Pain & Self & Partner & Baby & Nurse & Physician & General & Overal \\
\hline \multirow{3}{*}{0} & Mean & 36.40 & 7.40 & 13.00 & 39.50 & 35.80 & 13.10 & 144.70 \\
\hline & Std. Deviation & 6.720 & 3.098 & 2.708 & 6.223 & 4.392 & 1.792 & 21.924 \\
\hline & Range & 19 & 8 & 8 & 20 & 12 & 5 & 65 \\
\hline \multirow{3}{*}{10} & Mean & 35.80 & 7.60 & 12.80 & 39.80 & 34.80 & 12.40 & 143.20 \\
\hline & Std. Deviation & 6.261 & 3.286 & 1.304 & 4.087 & 4.604 & 1.673 & 19.097 \\
\hline & Range & 15 & 8 & 3 & 9 & 10 & 4 & 47 \\
\hline \multirow{3}{*}{20} & Mean & 38.50 & 8.50 & 13.33 & 40.17 & 33.83 & 11.83 & 146.17 \\
\hline & Std. Deviation & 6.124 & 1.517 & 1.366 & 2.787 & 5.981 & 2.483 & 17.904 \\
\hline & Range & 15 & 4 & 3 & 7 & 17 & 5 & 43 \\
\hline \multirow{3}{*}{30} & Mean & 37.38 & 8.50 & 13.00 & 39.38 & 35.00 & 12.75 & 146.00 \\
\hline & Std. Deviation & 4.033 & 1.512 & 1.309 & 3.962 & 4.071 & 1.389 & 14.392 \\
\hline & Range & 13 & 4 & 3 & 10 & 10 & 4 & 38 \\
\hline \multirow{3}{*}{40} & Mean & 36.17 & 7.83 & 12.67 & 37.67 & 34.00 & 13.17 & 141.50 \\
\hline & Std. Deviation & 6.014 & 2.041 & 2.658 & 4.082 & 3.578 & .983 & 14.096 \\
\hline & Range & 18 & 5 & 7 & 11 & 10 & 2 & 41 \\
\hline \multirow{3}{*}{50} & Mean & 33.80 & 8.35 & 12.60 & 38.00 & 33.25 & 11.65 & 137.65 \\
\hline & Std. Deviation & 6.178 & 1.843 & 2.137 & 5.390 & 5.562 & 2.323 & 21.441 \\
\hline & Range & 25 & 7 & 6 & 18 & 18 & 6 & 78 \\
\hline \multirow{3}{*}{60} & Mean & 33.55 & 8.09 & 11.45 & 36.36 & 31.91 & 12.45 & 133.82 \\
\hline & Std. Deviation & 3.804 & 1.578 & 2.252 & 3.233 & 3.270 & 1.128 & 11.522 \\
\hline & Range & 12 & 4 & 6 & 12 & 13 & 4 & 45 \\
\hline \multirow{3}{*}{70} & Mean & 34.40 & 7.10 & 11.30 & 36.30 & 31.90 & 12.00 & 133.00 \\
\hline & Std. Deviation & 8.859 & 2.234 & 3.498 & 10.467 & 9.527 & 2.160 & 28.225 \\
\hline & Range & 25 & 6 & 9 & 36 & 32 & 6 & 79 \\
\hline \multirow{3}{*}{80} & Mean & 35.27 & 8.36 & 13.73 & 41.00 & 35.45 & 12.27 & 146.09 \\
\hline & Std. Deviation & 6.754 & 2.157 & 1.191 & 3.317 & 4.034 & 1.954 & 16.483 \\
\hline & Range & 21 & 6 & 3 & 9 & 12 & 6 & 49 \\
\hline
\end{tabular}




\section{Continued}

\begin{tabular}{|c|c|c|c|c|c|c|c|c|}
\hline & Mean & 36.00 & 8.00 & 14.00 & 36.00 & 32.00 & 12.00 & 138.00 \\
\hline \multirow[t]{3}{*}{90} & Std. Deviation & . & . & . & . & . & . & . \\
\hline & Range & 0 & 0 & 0 & 0 & 0 & 0 & 0 \\
\hline & Mean & 30.25 & 8.42 & 10.67 & 39.00 & 35.08 & 12.42 & 135.83 \\
\hline \multirow[t]{3}{*}{100} & Std. Deviation & 6.181 & 1.443 & 3.393 & 4.690 & 3.988 & 1.165 & 7.481 \\
\hline & Range & 16 & 5 & 12 & 12 & 12 & 4 & 27 \\
\hline & Mean & 34.66 & 8.06 & 12.38 & 38.54 & 33.97 & 12.31 & 139.87 \\
\hline \multirow[t]{2}{*}{ Total } & Std. Deviation & 6.328 & 2.019 & 2.485 & 5.383 & 5.179 & 1.807 & 18.212 \\
\hline & Range & 26 & 8 & 12 & 36 & 32 & 7 & 84 \\
\hline
\end{tabular}

Table 10. Self partner baby nurse physician general overall * childbirth pain.

\begin{tabular}{|c|c|c|c|c|c|c|c|c|}
\hline & lbirth Pain & Self & Partner & Baby & Nurse & Physician & General & Overall \\
\hline \multirow{3}{*}{0} & Mean & 37.67 & 8.62 & 12.57 & 41.00 & 36.71 & 12.95 & 149.29 \\
\hline & Std. Deviation & 5.266 & 1.987 & 3.010 & 3.860 & 3.495 & 1.687 & 15.405 \\
\hline & Range & 17 & 8 & 12 & 12 & 9 & 5 & 42 \\
\hline \multirow{3}{*}{10} & Mean & 35.40 & 8.00 & 12.40 & 38.80 & 34.20 & 12.70 & 141.50 \\
\hline & Std. Deviation & 5.854 & 2.494 & 1.955 & 4.590 & 4.185 & 1.337 & 17.213 \\
\hline & Range & 20 & 8 & 6 & 14 & 11 & 4 & 51 \\
\hline \multirow{3}{*}{20} & Mean & 37.60 & 8.20 & 11.40 & 37.60 & 33.80 & 11.20 & 139.80 \\
\hline & Std. Deviation & 4.219 & 0.447 & 1.949 & 1.140 & 1.643 & 2.168 & 9.094 \\
\hline & Range & 10 & 1 & 5 & 3 & 4 & 5 & 21 \\
\hline \multirow{3}{*}{30} & Mean & 34.20 & 7.60 & 13.40 & 39.20 & 32.60 & 12.80 & 139.80 \\
\hline & Std. Deviation & 4.087 & 2.191 & 1.140 & 3.768 & 7.021 & 1.304 & 16.115 \\
\hline & Range & 9 & 4 & 3 & 8 & 17 & 3 & 38 \\
\hline \multirow{3}{*}{35} & Mean & 31.00 & 6.00 & 13.00 & 36.00 & 31.00 & 12.00 & 129.00 \\
\hline & Std. Deviation & . & . & . & . & . & . & . \\
\hline & Range & 0 & 0 & 0 & 0 & 0 & 0 & 0 \\
\hline \multirow{3}{*}{40} & Mean & 45.00 & 10.00 & 15.00 & 38.50 & 36.00 & 14.00 & 158.50 \\
\hline & Std. Deviation & 0.000 & 0.000 & 0.000 & 0.707 & 1.414 & 0.000 & 2.121 \\
\hline & Range & 0 & 0 & 0 & 1 & 2 & 0 & 3 \\
\hline
\end{tabular}




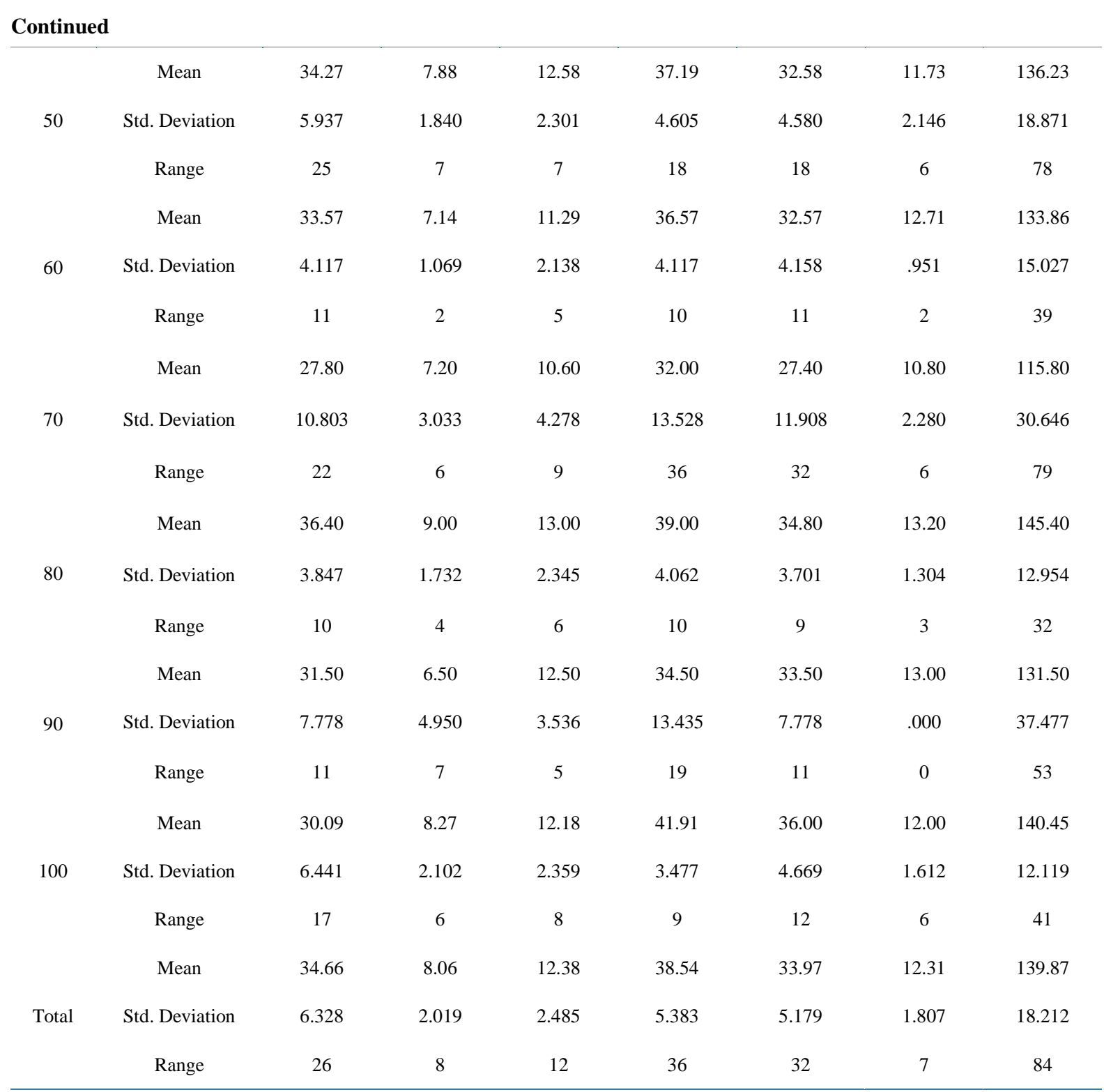

mainly because multiparous women perceived a successful and satisfied childbirth birth experience as a healthy baby being delivered. In addition, these women were unprejudiced and willing to compromise about their childbirth satisfaction. Also, primiparous women had a great fear of the unknown during their first delivery.

In addition, women with an educational level of college and more were more satisfied with the childbirth experience than women with an educational level of high school or less. It is maybe due to the fact that highly-educated women were more exposed to the childbirth preparation methods such as reading books, attending classes or making a childbirth plan. Plus, highly-educated females will have higher levels of self-efficacy and possess numerous coping strategies to deal with pain during labor and delivery.

Furthermore, it was deduced during this study that unemployed women were more satisfied with the childbirth experience compared to employed mothers. This could be explained by the amount of stress that a pregnant woman will face during her employment. This will lead to a negative impact on her pregnancy and satisfaction with the childbirth experience especially because childbearing is a critical phase in a woman's life filled with anxiety, depression and diminished quality of life. And unemployed women will have more free time in order to read books, watch videos and attend classes; which all lead to a more positive childbirth experience.

Additionally, females with higher income were found to be more satisfied with the childbirth experience. It 
Table 11. Self partner baby nurse physician general overall * childbirth expectations.

\begin{tabular}{|c|c|c|c|c|c|c|c|c|}
\hline \multicolumn{2}{|c|}{ Childbirth Expectations } & \multirow{2}{*}{$\begin{array}{c}\text { Self } \\
30.40\end{array}$} & \multirow{2}{*}{$\begin{array}{c}\text { Partner } \\
7.40\end{array}$} & \multirow{2}{*}{$\begin{array}{l}\text { Baby } \\
11.60\end{array}$} & \multirow{2}{*}{\begin{tabular}{|l} 
Nurse \\
32.60
\end{tabular}} & \multirow{2}{*}{$\begin{array}{c}\text { Physician } \\
28.60\end{array}$} & \multirow{2}{*}{$\begin{array}{c}\text { General } \\
11.20\end{array}$} & \multirow{2}{*}{$\begin{array}{l}\text { Overall } \\
121.80\end{array}$} \\
\hline & Mean & & & & & & & \\
\hline \multirow[t]{3}{*}{1} & Std. Deviation & 5.595 & 3.578 & 2.074 & 15.339 & 12.876 & 2.490 & 27.977 \\
\hline & Range & 14 & 7 & 5 & 35 & 32 & 5 & 67 \\
\hline & Mean & 35.07 & 8.21 & 11.86 & 37.57 & 33.07 & 12.57 & 138.36 \\
\hline \multirow[t]{3}{*}{2} & Std. Deviation & 6.788 & 1.847 & 3.394 & 2.954 & 3.562 & 1.651 & 15.077 \\
\hline & Range & 18 & 4 & 12 & 9 & 11 & 6 & 45 \\
\hline & Mean & 34.42 & 8.02 & 12.60 & 38.62 & 34.15 & 12.13 & 139.85 \\
\hline \multirow[t]{3}{*}{3} & Std. Deviation & 5.953 & 1.944 & 2.093 & 4.423 & 4.270 & 1.712 & 16.145 \\
\hline & Range & 25 & 8 & 8 & 18 & 18 & 6 & 78 \\
\hline & Mean & 36.10 & 8.24 & 12.29 & 40.38 & 35.33 & 12.90 & 145.24 \\
\hline \multirow[t]{3}{*}{4} & Std. Deviation & 7.106 & 2.022 & 2.969 & 4.466 & 5.266 & 1.921 & 21.333 \\
\hline & Range & 26 & 6 & 9 & 12 & 17 & 6 & 68 \\
\hline & Mean & 34.66 & 8.06 & 12.38 & 38.54 & 33.97 & 12.31 & 139.87 \\
\hline \multirow[t]{2}{*}{ Total } & Std. Deviation & 6.328 & 2.019 & 2.485 & 5.383 & 5.179 & 1.807 & 18.212 \\
\hline & Range & 26 & 8 & 12 & 36 & 32 & 7 & 84 \\
\hline
\end{tabular}

Table 12. Self partner baby nurse physician general overall * length of labor.

\begin{tabular}{|c|c|c|c|c|c|c|c|c|}
\hline \multicolumn{2}{|c|}{ Length of Labor } & \multirow{2}{*}{$\begin{array}{c}\text { Self } \\
31.67\end{array}$} & \multirow{2}{*}{$\begin{array}{c}\text { Partner } \\
6.00\end{array}$} & \multirow{2}{*}{$\begin{array}{l}\text { Baby } \\
12.00\end{array}$} & \multirow{2}{*}{$\begin{array}{l}\text { Nurse } \\
37.00\end{array}$} & \multirow{2}{*}{$\begin{array}{c}\text { Physician } \\
31.33\end{array}$} & \multirow{2}{*}{$\begin{array}{c}\text { General } \\
9.67\end{array}$} & \multirow{2}{*}{$\begin{array}{c}\text { Overall } \\
127.67\end{array}$} \\
\hline & Mean & & & & & & & \\
\hline \multirow[t]{3}{*}{$0.16 \mathrm{hr}$} & Std. Deviation & 5.774 & 3.464 & 0.000 & 1.732 & 2.887 & 1.155 & 12.702 \\
\hline & Range & 10 & 6 & 0 & 3 & 5 & 2 & 22 \\
\hline & Mean & 34.00 & 10.00 & 15.00 & 38.00 & 34.00 & 14.00 & 140.00 \\
\hline \multirow[t]{3}{*}{$0.16 \mathrm{hrs}$} & Std. Deviation & . & . & . & . & . & . & . \\
\hline & Range & 0 & 0 & 0 & 0 & 0 & 0 & 0 \\
\hline & Mean & 37.67 & 10.00 & 13.67 & 40.67 & 36.00 & 13.33 & 151.33 \\
\hline \multirow[t]{4}{*}{$0.33 \mathrm{hr}$} & Std. Deviation & 2.887 & .000 & 1.528 & 4.509 & 4.000 & 1.155 & 12.662 \\
\hline & Range & 5 & 0 & 3 & 9 & 8 & 2 & 25 \\
\hline & Mean & 39.00 & 5.00 & 15.00 & 39.00 & 34.00 & 14.00 & 146.00 \\
\hline & Std. Deviation & . & . & . & . & . & . & . \\
\hline \multirow{4}{*}{$0.33 \mathrm{hrs}$} & Range & 0 & 0 & 0 & 0 & 0 & 0 & 0 \\
\hline & Mean & 37.40 & 8.40 & 13.20 & 33.20 & 30.00 & 11.60 & 133.80 \\
\hline & Std. Deviation & 3.050 & 2.074 & 2.049 & 14.114 & 12.748 & 2.302 & 29.601 \\
\hline & Range & 7 & 5 & 5 & 35 & 32 & 6 & 72 \\
\hline
\end{tabular}




\section{Continued}

\begin{tabular}{|c|c|c|c|c|c|c|c|c|}
\hline & Mean & 19.00 & 4.00 & 6.00 & 35.00 & 28.00 & 10.00 & 102.00 \\
\hline \multirow[t]{3}{*}{$0.67 \mathrm{hr}$} & Std. Deviation & 0.000 & 0.000 & 0.000 & 0.000 & 0.000 & 0.000 & 0.000 \\
\hline & Range & 0 & 0 & 0 & 0 & 0 & 0 & 0 \\
\hline & Mean & 39.00 & 9.00 & 14.50 & 43.50 & 39.00 & 14.50 & 159.50 \\
\hline \multirow[t]{3}{*}{$0.75 \mathrm{hr}$} & Std. Deviation & 1.414 & 1.414 & .707 & 2.121 & 1.414 & .707 & 7.778 \\
\hline & Range & 2 & 2 & 1 & 3 & 2 & 1 & 11 \\
\hline & Mean & 36.60 & 8.40 & 13.60 & 39.60 & 36.40 & 13.40 & 148.00 \\
\hline \multirow[t]{3}{*}{$1 \mathrm{hr}$} & Std. Deviation & 6.656 & 1.673 & 1.517 & 5.941 & 5.320 & 1.342 & 20.928 \\
\hline & Range & 18 & 4 & 3 & 15 & 13 & 3 & 54 \\
\hline & Mean & 30.00 & 10.00 & 12.00 & 42.00 & 40.00 & 13.00 & 147.00 \\
\hline
\end{tabular}

1.5 hrs Std. Deviation

\begin{tabular}{|c|c|c|c|c|c|c|c|c|}
\hline & Range & 0 & 0 & 0 & 0 & 0 & 0 & 0 \\
\hline & Mean & 39.50 & 9.67 & 14.00 & 40.00 & 35.83 & 12.83 & 151.83 \\
\hline \multirow[t]{3}{*}{$10 \mathrm{hrs}$} & Std. Deviation & 6.380 & .816 & 1.673 & 4.382 & 3.869 & 2.137 & 18.027 \\
\hline & Range & 16 & 2 & 4 & 10 & 9 & 6 & 45 \\
\hline & Mean & 36.00 & 8.00 & 11.00 & 36.00 & 32.00 & 12.00 & 135.00 \\
\hline
\end{tabular}

11 hrs Std. Deviation

\begin{tabular}{|c|c|c|c|c|c|c|c|c|}
\hline & Range & 0 & 0 & 0 & 0 & 0 & 0 & 0 \\
\hline \multirow{3}{*}{$12 \mathrm{hrs}$} & Mean & 36.00 & 9.60 & 14.00 & 42.20 & 37.40 & 13.60 & 152.80 \\
\hline & Std. Deviation & 4.062 & .894 & 1.225 & 4.658 & 3.647 & 2.191 & 15.707 \\
\hline & Range & 9 & 2 & 3 & 11 & 9 & 5 & 38 \\
\hline \multirow{3}{*}{$13 \mathrm{hrs}$} & Mean & 31.67 & 6.67 & 9.67 & 35.67 & 31.67 & 11.00 & 126.33 \\
\hline & Std. Deviation & 2.309 & 1.155 & 1.155 & 0.577 & 0.577 & 1.732 & 2.887 \\
\hline & Range & 4 & 2 & 2 & 1 & 1 & 3 & 5 \\
\hline \multirow{3}{*}{$14 \mathrm{hrs}$} & Mean & 37.00 & 7.75 & 13.00 & 40.25 & 33.50 & 12.25 & 143.75 \\
\hline & Std. Deviation & 9.487 & 2.630 & 1.414 & 1.500 & 4.435 & 2.217 & 18.626 \\
\hline & Range & 21 & 6 & 3 & 3 & 10 & 5 & 41 \\
\hline \multirow{3}{*}{$17 \mathrm{hrs}$} & Mean & 38.50 & 8.00 & 13.50 & 39.00 & 34.50 & 13.50 & 147.00 \\
\hline & Std. Deviation & 0.707 & 2.828 & 2.121 & 5.657 & 6.364 & 0.707 & 16.971 \\
\hline & Range & 1 & 4 & 3 & 8 & 9 & 1 & 24 \\
\hline
\end{tabular}




\section{Continued}

\begin{tabular}{|c|c|c|c|c|c|c|c|c|}
\hline & Mean & 27.00 & 6.00 & 11.00 & 35.00 & 31.00 & 9.00 & 119.00 \\
\hline \multirow[t]{3}{*}{$18 \mathrm{hrs}$} & Std. Deviation & . & . & . & . & . & . & . \\
\hline & Range & 0 & 0 & 0 & 0 & 0 & 0 & 0 \\
\hline & Mean & 35.50 & 8.25 & 11.25 & 39.75 & 35.75 & 12.50 & 143.00 \\
\hline \multirow[t]{3}{*}{$2 \mathrm{hrs}$} & Std. Deviation & 1.732 & 1.708 & 2.986 & 4.113 & 3.403 & .577 & 6.055 \\
\hline & Range & 4 & 4 & 7 & 9 & 7 & 1 & 14 \\
\hline & Mean & 28.00 & 8.00 & 15.00 & 38.00 & 30.00 & 11.00 & 130.00 \\
\hline \multirow[t]{3}{*}{$24 \mathrm{hrs}$} & Std. Deviation & . & . & . & . & . & . & . \\
\hline & Range & 0 & 0 & 0 & 0 & 0 & 0 & 0 \\
\hline & Mean & 33.00 & 6.80 & 12.00 & 37.20 & 32.20 & 12.40 & 133.60 \\
\hline \multirow[t]{3}{*}{$3 \mathrm{hrs}$} & Std. Deviation & 4.899 & 1.095 & 1.871 & 4.764 & 4.764 & .548 & 15.453 \\
\hline & Range & 12 & 2 & 4 & 13 & 13 & 1 & 42 \\
\hline & Mean & 29.00 & 7.67 & 11.67 & 40.17 & 33.67 & 11.50 & 133.67 \\
\hline \multirow[t]{3}{*}{$4 \mathrm{hrs}$} & Std. Deviation & 8.173 & .816 & 1.366 & 5.193 & 7.174 & 1.975 & 15.397 \\
\hline & Range & 20 & 2 & 4 & 13 & 18 & 6 & 44 \\
\hline & Mean & 33.45 & 8.09 & 12.36 & 38.36 & 34.27 & 12.64 & 139.18 \\
\hline \multirow[t]{3}{*}{$5 \mathrm{hrs}$} & Std. Deviation & 4.865 & 2.119 & 2.292 & 5.971 & 4.541 & 1.286 & 17.262 \\
\hline & Range & 17 & 7 & 6 & 20 & 12 & 5 & 60 \\
\hline & Mean & 33.92 & 7.33 & 10.75 & 36.75 & 32.25 & 11.92 & 132.92 \\
\hline \multirow[t]{3}{*}{$6 \mathrm{hrs}$} & Std. Deviation & 5.648 & 2.640 & 2.563 & 5.154 & 5.328 & 1.676 & 18.540 \\
\hline & Range & 23 & 8 & 7 & 18 & 17 & 5 & 73 \\
\hline & Mean & 34.00 & 9.00 & 11.29 & 38.00 & 34.14 & 12.14 & 138.57 \\
\hline \multirow[t]{3}{*}{$7 \mathrm{hrs}$} & Std. Deviation & 5.447 & 1.291 & 4.192 & 4.472 & 3.625 & 2.478 & 15.361 \\
\hline & Range & 15 & 3 & 12 & 12 & 10 & 6 & 51 \\
\hline & Mean & 36.50 & 7.75 & 13.75 & 39.50 & 35.50 & 11.75 & 144.75 \\
\hline \multirow[t]{3}{*}{$8 \mathrm{hrs}$} & Std. Deviation & 10.376 & 2.062 & .957 & 4.359 & 3.697 & .500 & 18.751 \\
\hline & Range & 22 & 5 & 2 & 9 & 8 & 1 & 39 \\
\hline & Mean & 40.20 & 8.80 & 14.20 & 40.40 & 35.40 & 13.20 & 152.20 \\
\hline \multirow[t]{3}{*}{$9 \mathrm{hrs}$} & Std. Deviation & 6.573 & 1.643 & 1.095 & 4.219 & 4.506 & 2.049 & 19.189 \\
\hline & Range & 12 & 3 & 2 & 8 & 9 & 4 & 38 \\
\hline & Mean & 34.66 & 8.06 & 12.38 & 38.54 & 33.97 & 12.31 & 139.87 \\
\hline \multirow[t]{2}{*}{ Total } & Std. Deviation & 6.328 & 2.019 & 2.485 & 5.383 & 5.179 & 1.807 & 18.212 \\
\hline & Range & 26 & 8 & 12 & 36 & 32 & 7 & 84 \\
\hline
\end{tabular}


Table 13. Self partner baby nurse physician general overall ${ }^{*}$ method of delivery.

\begin{tabular}{|c|c|c|c|c|c|c|c|c|}
\hline \multicolumn{2}{|c|}{ Method of Delivery } & \multirow{2}{*}{$\begin{array}{c}\text { Self } \\
34.89\end{array}$} & \multirow{2}{*}{$\begin{array}{c}\text { Partner } \\
8.00\end{array}$} & \multirow{2}{*}{$\begin{array}{l}\text { Baby } \\
12.04\end{array}$} & \multirow{2}{*}{$\begin{array}{l}\text { Nurse } \\
36.71\end{array}$} & \multirow{2}{*}{$\begin{array}{c}\text { Physician } \\
31.86\end{array}$} & \multirow{2}{*}{$\begin{array}{c}\text { General } \\
11.82\end{array}$} & \multirow{2}{*}{$\begin{array}{l}\text { overall } \\
135.32\end{array}$} \\
\hline & Mean & & & & & & & \\
\hline Vaginal Birth & Std. Deviation & 6.106 & 1.764 & 2.219 & 7.246 & 7.106 & 2.229 & 21.313 \\
\hline & Range & 25 & 7 & 8 & 36 & 32 & 7 & 84 \\
\hline & Mean & 35.25 & 8.39 & 12.96 & 40.00 & 35.00 & 12.39 & 144.00 \\
\hline \multirow[t]{3}{*}{$\begin{array}{c}\text { Use of Vacuum Extractor or } \\
\text { Forceps }\end{array}$} & Std. Deviation & 7.643 & 1.969 & 2.236 & 3.991 & 3.820 & 1.892 & 16.607 \\
\hline & Range & 25 & 8 & 8 & 11 & 12 & 6 & 51 \\
\hline & Mean & 34.14 & 7.89 & 12.23 & 38.77 & 34.66 & 12.57 & 140.14 \\
\hline \multirow[t]{3}{*}{ Caesarean } & Std. Deviation & 5.618 & 2.212 & 2.769 & 4.487 & 4.097 & 1.388 & 16.752 \\
\hline & Range & 26 & 8 & 12 & 20 & 13 & 5 & 68 \\
\hline & Mean & 34.66 & 8.06 & 12.38 & 38.54 & 33.97 & 12.31 & 139.87 \\
\hline \multirow[t]{2}{*}{ Total } & Std. Deviation & 6.328 & 2.019 & 2.485 & 5.383 & 5.179 & 1.807 & 18.212 \\
\hline & Range & 26 & 8 & 12 & 36 & 32 & 7 & 84 \\
\hline
\end{tabular}

Table 14. Self partner baby nurse physician general overall * epidural.

\begin{tabular}{|c|c|c|c|c|c|c|c|c|}
\hline & Epidural & Self & Partner & Baby & Nurse & Physician & General & Overall \\
\hline \multirow{3}{*}{ Yes } & Mean & 35.40 & 8.16 & 12.64 & 39.10 & 34.02 & 12.26 & 141.58 \\
\hline & Std. Deviation & 6.803 & 1.754 & 2.183 & 4.001 & 4.533 & 1.957 & 16.894 \\
\hline & Range & 25 & 8 & 8 & 13 & 18 & 6 & 60 \\
\hline \multirow{3}{*}{ No } & Mean & 30.80 & 8.20 & 10.60 & 29.60 & 26.40 & 10.00 & 115.60 \\
\hline & Std. Deviation & 7.014 & 3.033 & 2.302 & 13.777 & 12.178 & 2.000 & 27.880 \\
\hline & Range & 18 & 7 & 6 & 36 & 32 & 5 & 65 \\
\hline \multirow{3}{*}{ Total } & Mean & 34.98 & 8.16 & 12.45 & 38.24 & 33.33 & 12.05 & 139.22 \\
\hline & Std. Deviation & 6.887 & 1.864 & 2.251 & 6.015 & 5.875 & 2.050 & 19.322 \\
\hline & Range & 25 & 8 & 8 & 36 & 32 & 7 & 84 \\
\hline
\end{tabular}

can be explained by the fact that these mothers will be able to attend pre-natal courses, read books and watch videos regarding the experience of labor and delivery. Also, these mothers with the higher income will have more money to have a high number of sessions with the doctor and to attend parent craft sessions. Plus, these women could afford undergoing epidural anesthesia which will reflect positively on their satisfaction. Finally, women with a higher monthly salary may have been treated differently by the medical staff especially during their stay in the hospital post-partum: bigger and more equipped room, unshared room with another patient...

As well, it was noted that mothers who had the opportunity for childbirth preparation were more satisfied with the childbirth experience than unprepared ones. Our findings confirm with the results of J. Gibbinset al. [22], J. Fenwick et al. [29] and R. Darvill et al. [30]. Reading books, watching videos, attending parent craft sessions or 
making plans were linked to a positive birth experience and a higher satisfaction regarding it. Prenatal courses and prenatal consultations achieved by midwives and physicians assisted in driving out and calming fears, and improving women's confidence and self-esteem. Additionally, women alleged that their planning assisted them to deal psychologically with the labor, they believed to be in the know about labor, were capable of making and were integrated in deciding and sensed to be in command during the labor.

Furthermore, just as J. Jomeen et al. [7], W. Christiaens et al. [20], P. Larkin et al. [21], J. Gibbins et al. [22], Y. Hauck et al. [23] and T. Lavender et al. [25] made it clear; personal control was found to be associated with a higher satisfaction with the childbirth experience. Women who had higher personal control were constantly informed throughout the course of delivery, allowed to craft informed choices and decisions which were imperative factors that will make women feel confident and satisfied with the childbirth experience.

Still, our results suggest that women with a high self-efficacy had a higher satisfaction with the childbirth experience. These findings support other reports that a high self efficacy was related to a higher satisfaction with the childbirth experience (C. Fisher et al. [24], D. Escott et al. [26]). Patients with a higher self-efficacy managed pain and coped with it the most. This led to a more positive experience. In addition, women with a low self-efficacy had high levels of fear, relied on others to make resolutions concerning their health and possessed drastically lower levels of self esteem and a reduced amount of satisfaction with the childbirth experience.

Plus, our findings confirmed with L. Callister et al. [28], but contrasted with P. Goodamn et al. [16], C. Kinsey et al. [18], C. Fisher et al. [24] and M. Mackey [27], stating that childbirth pain contributed in a positive birth experience. Some women expressed a feeling of triumph and fulfillment in their aptitude to deal with severe pain, which improved their awareness of self-efficacy. This will eventually lead to a higher satisfaction with the delivery process.

In addition, it was denoted that females with fulfilled expectations regarding their childbirth experience had higher satisfaction than those with unfulfilled ones. These findings support the results of W. Christiaens et al. [20] indicating that unfulfilled expectations trouble the woman and endangers both self-evaluations and bonding with others. To be exact, the deviation from what is typical or predictable produces anguish. Satisfaction is a state of mind displaying the assessment of the birth experience as a whole weight against numerous antenatal principles and expectations. If expectations are met, the equivalent values and beliefs are assured. If not, disagrees occur, which may generate agony and negative childbirth experience.

Moreover, it was perceived in this study that shorter periods of labor will leave the mother in a state of higher satisfaction with the childbirth experience. Our results support the findings of A. Nystedt et al. [32] stating that women caught up in a prolonged labor reported emotions of pain and fright while being not in control and dependant on others. The discomfort and fright experienced by the mothers was perceived as a critical event mixed with deep feelings of misery and shock. Mothers feared for their own safety and the welfare of their infants.

Additionally, patients who had underwent instrumented vaginal delivery and cesarean delivery were found to be more satisfied with the childbirth experience compared with the women of the normal vaginal delivery group. Our results are with accordance of the findings of T. Lavender et al. [15], but they differ from the results of C. B. Kinsey et al. [19] and Y. Hauck et al. [13]. It's may be due to the fact that these women sensed higher level of control, preservation of the body's integrity during a less traumatizing and self-mutilate experience. And also females may have seen that interventions positively contributed to their childbirth experience when unusual labor pattern sets in.

Finally, women who have undergone vaginal delivery and received epidural anesthesia were found to be more satisfied than the women who have not. The results differ from the findings of L.C. Callister et al. [28]. It can be explained by the fact that these women weren't distracted by the delivery/labor pain, sensed higher levels of control and felt less traumatized so their satisfaction with the childbirth experience was higher.

\section{Conclusions}

Conclusions of the study ought to be well thought-out in view of the probable limitations. It has been assumed that interviewing mothers shortly subsequent to delivery, like we have accomplished, might guide to an amplification of the satisfaction as a consequence of the ecstasy with the denial. Moreover, the sample size is small and non-randomly chosen, so the findings aren't generalizable to all post-partum women across Lebanon.

Regardless of the limitations, this study demonstrates that satisfaction with the childbirth experience is multidimensional with diverse factors foreseeing the various dimensions of satisfaction. Our findings consist that for a positive childbirth experience different factors interfere: Advanced maternal age, multiparous, high monthly in- 
come, unemployed, high educational level, childbirth preparation, high personal control, high self-efficacy, high levels of labor and childbirth pain, short duration of labor, instrumented delivery and receiving epidural anesthesia.

So as child delivery happens to be a progressively more medicalized process, distinguished by technology and increasing interventional rates, it is imperative to investigate satisfaction with the childbirth experience in the need that health care professionals and maternity systems can better conform to mothers' individual requirements and preferences.

\section{Acknowledgements}

For my thesis director Dr. Samir Tarraf; Head of the Anesthesiology and Reanimation department at CHU-NDS, Jbeil:

You did me the honor of proposing the subject of this thesis and accepting to direct this work. Your help, disponibility, your support and remarks guided me in order to fully achieve my thesis.

Please accept my sincere acknowledgments and eternal gratitude.

For Dr. Wadih Ghaname; Head of the Obstetrics and Gynecology Department at CHU-NDS, Jbeil:

I want to thank you for your approval regarding interviewing the patients that have just given birth on the floor. This was crucial for completing my study.

For Dr. Joseph Istanbouli; Head of the Obstetrics and Gynecology Department at Saint Georges Hospital, Ajaltoun:

I want to thank you for your approval regarding interviewing the patients that have just given birth on the floor. This was crucial for completing my study.

Also, I want to thank all the midwives that help me in collecting the data from the women who have given birth, especially Miss Sophia Abi Khalil.

For my mother, you always stand by my side. You constantly support me and give me affection. You always guide me when you find it is necessary and it is because of you I am here today.

For my father, I know you are proud of me standing right here. You always support me during my studies and I am thankful for that.

For my sister Abir and my brother Jad, I am grateful for your unconditional love and unlimited support.

For my friends and colleagues, I am thankful for all the time we share together and for the memories that I have in my mind.

\section{References}

[1] Rubin, R. (1961) Puerperal Change. Nursing Outlook, 9, 753-755.

[2] Brockington, I.F. (2004) Diagnosis and Management of Post-Partum Disorders: A Review. World Psychiatry, 3, 89-95.

[3] Lundgren, I. (2005) Swedish Women’s Experience of Childbirth 2 Years after Birth. Midwifery, 21, 346-354. http://dx.doi.org/10.1016/j.midw.2005.01.001

[4] Mozingo, J.N., Davis, M.W., Thomas, S.P. and Droppleman, P.G. (2002) "I Felt Violated”: Women’s Experience of Childbirth-Associated Anger. NCN, American Journal of Maternal Child Nursing, 27, 342-348. http://dx.doi.org/10.1097/00005721-200211000-00009

[5] Lee, C. (2000) Psychology of Women’s Health: A Critique. In: Ussher, J.M., Ed., Women’s Health: Contemporary International Perspectives, British Psychological Society, Leicester.

[6] O’Connor, T.G., Heron, J., Golding, J., Beveridge, M. and Glover, V. (2002) Maternal Antenatal Anxiety and Children Behavioural/ Emotional Problems at 4 Years: Report from the Avon Longitudinal Study of Parents and Children. The British Journal of Psychiatry, 180, 502-508. http://dx.doi.org/10.1192/bjp.180.6.502

[7] Jomeen, J. (2004) The Importance of Assessing Psychological Status during Pregnancy, Childbirth and the Postnatal Period as a Multidimensional Construct: A Literature Review. Clinical Effectiveness in Nursing, 8, 143-155. http://dx.doi.org/10.1016/j.cein.2005.02.001

[8] Jones, D.R., Rantakallio, P., Hartikainen, A.L., Matti, I. and Sipila, P. (1998) Schizophrenia as a Long Term Outcome of Pregnancy, Delivery and Perinatal Complications: A 28 Yeas Follow up of the 1966 North Finland Population Birth Cohort. American Journal of Psychiatry, 155, 355-364.

[9] Seeley, S., Murray, L. and Cooper, P.J. (1996) The Outcome for Mothers and Babies of Health Visitor Intervention. Health Visitor, 69, 135-138.

[10] Otchet, F., Carey, M.A. and Adam, L. (1999) General Health and Psychological Symptom Status in Pregnancy and the 
Puerperium. Obstetrics and Gynaecology, 94, 935-941. http://dx.doi.org/10.1016/S0029-7844(99)00439-1

[11] Mckee, M.D., Cunningham, M., Jankowski, K.R.B. and Zayas, L. (2001) Health-Related Functional Status in Pregnancy: Relationship to Depression and Social Support in a Multi-Ethnic Population. Obstetrics and Gynecology, 97, 993998. http://dx.doi.org/10.1016/S0029-7844(01)01377-1

[12] Wilkie, G. and Shapiro, C.M. (1992) Sleep Deprivation and the Postnatal Blues. Journal of Psychosomatic Research, 36, 309-316. http://dx.doi.org/10.1016/0022-3999(92)90067-C

[13] McVeigh, C. and Smith, M. (2000) A Comparison of Adult and Teenage Mother's Self-Esteem and Satisfaction with Social Support. Midwifery, 16, 269-276. http://dx.doi.org/10.1054/midw.2000.0226

[14] Jenkin, W. and Tiggemann, M. (1997) Psychological Effects of Weight Retained after Pregnancy. Women and Heath, 25, 89-98. http://dx.doi.org/10.1300/J013v25n01_06

[15] Bowman, M.A, Herndon, A., Sharp, P.C. and Digman, M.B. (1992) Assessment of the Patient-Doctor Interaction Scale for Measuring Patient Satisfaction. Patient Education and Counseling, 19, 75-80. http://dx.doi.org/10.1016/0738-3991(92)90103-P

[16] Goodman, P., Mackey, M.C. and Tavakoli, A. (2004) Factors Related to Childbirth Satisfaction. Journal of Advanced Nursing, 46, 212-219. http://dx.doi.org/10.1111/j.1365-2648.2003.02981.x

[17] Simkin, P. (1991) Just Another Day in a Woman's life? Women’s Long-Term Perceptions of Their First Birth Experience. Part I. Birth, 18, 203-211. http://dx.doi.org/10.1111/j.1523-536X.1991.tb00103.x

[18] Larsson, C., Saltvedt, S., Edman, G., Wiklund, G. and Andolf, E. (2011) Factors Independently Related to a Negative Birth Experience in First-Time Mothers. Sexual \& Reproductive Healthcare, 2, 83-89. http://dx.doi.org/10.1016/j.srhc.2010.11.003

[19] Kinsey, C. and Hupcey, J. (2013) State of the Science of Maternal-Infant Bonding: A Principle-Based Concept of Analysis. Midwifery, 29, 1314-1320. http://dx.doi.org/10.1016/j.midw.2012.12.019

[20] Christiaens, W. and Bracke, P. (2007) Assessment of Social Psychological Determinants of Satisfaction with Childbirth in a Cross-National Perspective. BMC Pregnancy and Childbirth, 7, 26. http://dx.doi.org/10.1186/1471-2393-7-26

[21] Larkin, P., Begley, C. and Devane, D. (2012) “Not Enough People to Look after You”: An Exploration of Women’s Experiences of Childbirth in the Republic of Ireland. Midwifery, 28, 98-105. http://dx.doi.org/10.1016/j.midw.2010.11.007

[22] Gibbins, J. and Thomson, A. (2001) Women’s Expectations and Experiences of Childbirth. Midwifery, 17, $302-313$. http://dx.doi.org/10.1054/midw.2001.0263

[23] Hauck, Y., Fenwick, J., Downie, J. and Butt, J. (2007) The Influence of Childbirth Expectations on Western Australian Women's Perceptions of Their Birth Experience. Midwifery, 23, 235-247. http://dx.doi.org/10.1016/j.midw.2006.02.002

[24] Fisher, C., Hauck, Y. and Fenwick, J. (2006) How Social Context Impacts on Women's Fears of Childbirth: A Western Australian Example. Social Science \& Medicine, 63, 65-75.

[25] Lavender, T., Walkinshaw, S. and Walton, I. (1999) A Prospective Study of Women's Views of Factors Contributing to a Positive Birth Experience. Midwifery, 15, 40-46. http://dx.doi.org/10.1016/S0266-6138(99)90036-0

[26] Escott, D., Slade, P. and Spiby, H. (2009) Preparation for Pain Management during Childbirth: The Psychological Aspects of Coping Strategy Development in Antenatal Education. Clinical Psychology Review, 29, 617-622. http://dx.doi.org/10.1016/j.cpr.2009.07.002

[27] Mackey, M.C. (1998) Women’s Evaluation of Their Labor and Delivery Experience. Nursing Connections, 11, 19-32.

[28] Callister, L., Khalaf, I., Kartchner, R., Semenic, S. and Vehvilainen-Julknen, K. (2003) The Pain of Childbirth: Perceptions of Culturally Diverse Women. Pain Management Nursing, 4, 145-154. http://dx.doi.org/10.1016/S1524-9042(03)00028-6

[29] Fenwick, J., Hauck, Y., Downie, J. and Butt, J. (2005) The Childbirth Expectations of a Self-Selected Cohort of Western Australian Women. Midwifery, 21, 23-35. http://dx.doi.org/10.1016/j.midw.2004.07.001

[30] Darvill, R., Skirton, H. and Farrand, P. (2010) Psychological Factors That Impact on Women's Experiences of FirstTime Motherhood: A Qualitative Study of the Transition. Midwifery, 26, 357-366. http://dx.doi.org/10.1016/j.midw.2008.07.006

[31] Kasrlstom, A., Nystedt, A. and Hildingsson, I. (2011) A Comparative Study of the Experience of Childbirth between Women Who Preferred and Had a Caesarean Section and Women Who Preferred and Had a Vaginal Birth. Sexual \& Reproductive Healthcare, 2, 93-99. http://dx.doi.org/10.1016/j.srhc.2011.03.002

[32] Nystedt, A., Högberg, U. and Lundman, B. (2006) Some Swedish Women’s Experiences of Prolonged Labour. Midwifery, 22, 56-65. http://dx.doi.org/10.1016/j.midw.2005.05.003 
Scientific Research Publishing (SCIRP) is one of the largest Open Access journal publishers. It is currently publishing more than 200 open access, online, peer-reviewed journals covering a wide range of academic disciplines. SCIRP serves the worldwide academic communities and contributes to the progress and application of science with its publication.

Other selected journals from SCIRP are listed as below. Submit your manuscript to us via either submit@scirp.org or Online Submission Portal.
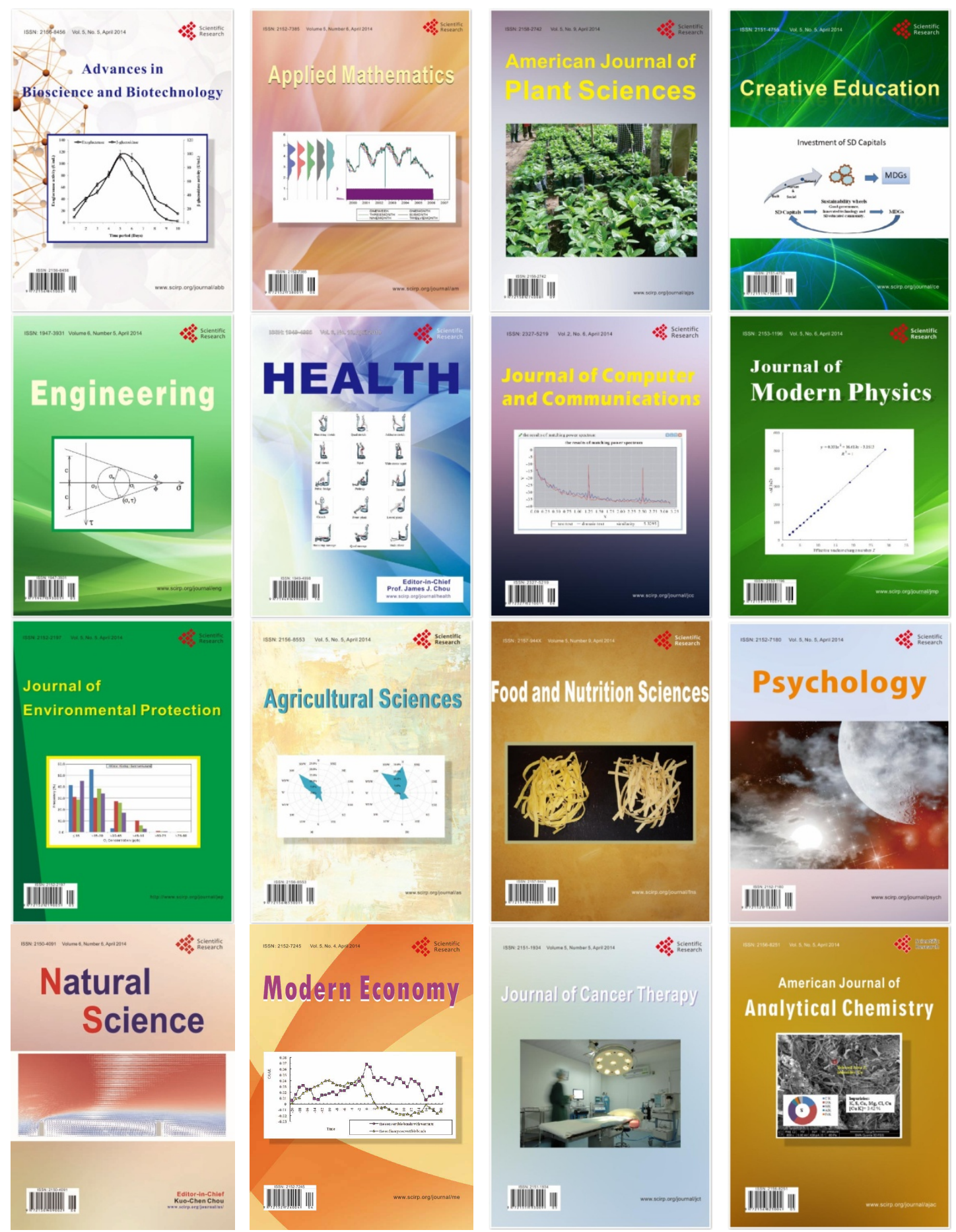